1985

\title{
Alfred of Sareshel's Commentary on the Pseudo Aristotelian De plantis: A Critical Edition
}

\author{
R. James Long \\ Fairfield University, rjlong@fairfield.edu
}

Follow this and additional works at: https://digitalcommons.fairfield.edu/philosophy-facultypubs Copyright 1985 Pontifical Institute of Mediaeval Studies

\section{Peer Reviewed}

\section{Repository Citation}

Long, R. James, "Alfred of Sareshel's Commentary on the Pseudo Aristotelian De plantis: A Critical Edition" (1985). Philosophy Faculty Publications. 15.

https://digitalcommons.fairfield.edu/philosophy-facultypubs/15

\section{Published Citation}

Long, R. James (1985). "Alfred of Sareshel's Commentary on the Pseudo Aristotelian De plantis: A Critical Edition," Mediaeval Studies 47 (1985) 125-67

This item has been accepted for inclusion in DigitalCommons@Fairfield by an authorized administrator of DigitalCommons@Fairfield. It is brought to you by DigitalCommons@Fairfield with permission from the rightsholder(s) and is protected by copyright and/or related rights. You are free to use this item in any way that is permitted by the copyright and related rights legislation that applies to your use. For other uses, you need to obtain permission from the rights-holder(s) directly, unless additional rights are indicated by a Creative Commons license in the record and/or on the work itself. For more information, please contact digitalcommons@fairfield.edu. 


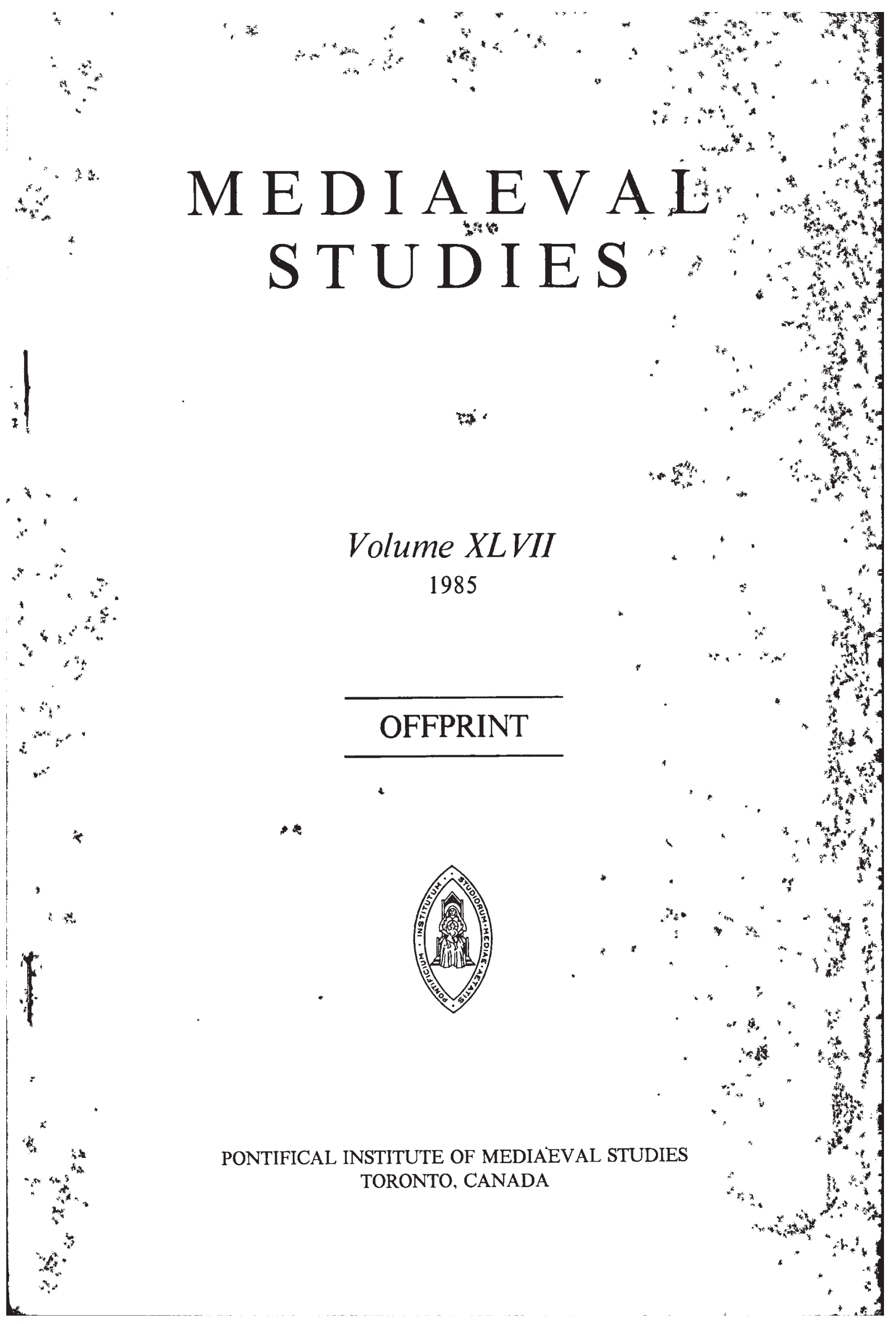




\section{CONTENTS}

J. Joseph Ryan (1906-1984)

Roger E. Reynolds

VII

James A. Weisheipl, O.P. (1923-1984)

Armand Maurer

XII

TExTs

The Nine Ways of Prayer of St. Dominic: A Textual Study and Critical Edition

Simon Tugwell

Alfred of Sareshel's Commentary on the Pseudo-Aristotelian De plantis: A Critical Edition

$R$. James Long

The Middle French Statutes of the Monarchical Order of the Ship

(Naples, 1381): A Critical Edition, with Introduction and Notes

D'A. J. D. Boulton

The Biblical Epigrams of Hildebert of Le Mans: A Critical Edition

A. B. Scott, Deirdre F. Baker and A. G. Rigg

ARTICLES

Addenda to Codices latini antiquiores

Bernhard Bischoff and Virginia Brown

Bishop Robert Grosseteste and His Cathedral Chapter: An Edition of the Chapter's Objections to Episcopal Visitation

F. A. C. Mantello

Trauma at Tortosa: The Testimony of Abraham Rimoch

Frank Talmage

A Fabliau in the Prologue to the Tale of Beryn

Bradley Darjes and Thomas Rendall

Miscellanea beneventana (II)

1. Beneventana-Fragmente liturgischer Bücher im Stadtarchiv Augsburg Raymund Kottje

2. A South Italian Ordination Allocution

Roger E. Reynolds 


\title{
ALFRED OF SARESHEL'S COMMENTARY ON THE PSEUDO-ARISTOTELIAN DE PLANTIS: A CRITICAL EDITION
}

\author{
R. James Long
}

I

$\mathrm{T}^{\mathrm{n}}$ RANSLATOR, commentator, and author in his own right, Alfred of Sareshel holds a place of prominence among those intellectual adventurers who introduced the natural philosophy of Aristotle to the Latin West. Not only was he the first Western writer to have displayed an extensive knowledge of the libri naturales, especially the biological works, ${ }^{1}$ he was also the precursor of a long line of scholastic commentators on these texts, ${ }^{2}$ thus earning from a contemporary the epithet 'dux naturae'. ${ }^{3}$

Despite his prominence, however, little is known with certainty about Alfred's life. The dedications of two of his works - the translation' of the De plantis to Roger of Hereford ${ }^{4}$ and his De motu cordis to Alexander Neckham ${ }^{5}$ - provide us with some clues regarding the dates of his literary

' See C. H. Haskins, Studies in the History of Mediaeval Science, 2nd edition (Cambridge, Mass., 1927), pp. 128-29, and S. D. Wingate, The Mediaeval Latin Versions of the Aristotelian Scientific Corpus, with Special Reference to the Biological Works (London, 1931), p. 27.

2 D. A. Callus, 'Introduction of Aristotelian Learning to Oxford', Proceedings of the British Academy 29 (1943) 10.

${ }^{3}$ The author, of the attribution is David of Dinant, whose Quaternuli were condemned to the fire by a papal decree in 1210; see M. Kurdziałek, 'David von Dinant als Ausleger der Aristotelischen Naturphilosophie' in Die A useinandersetzungen an der Pariser. Universität im xIt!. Jahrhundert, ed. A. Zimmermann (Miscellanea mediaevalia 10; Berlin-New.York, 1976), p. 187. Roger Bacon, on the other hand, includes Alfred in his sweeping condemnation of those translators (Gerard of Cremona, Michael Scot, Herman the German, and William of Moerbeke) in whose 'works there were so many mistakes that none of them deserved any, praise ('accidit tanta falsitas in eorum operibus, quod nullus sufficit admirari'); see Compendium studii philosophiae, ed. J. S. Brewer, in Opera quaedam hactenus inedita 3 (London, 1859), p. 471. Notwithstanding, Bacon was not above making extensive use of Alfred's commentaries" see A. Pelzer, 'Une source inconnue de Roger Bacon: Alfred de Sareshel, commentateur des Météorologiques d'Aristote', Archivum franciscanum historicum 12 (1919) 44:67.

4 Nicolai Damasceni De plantis libri duo Aristoteli vulgo adscripti, ed. E. H. F. Meyer (Leipzig, 1841), p. 3 n. 1.

s C. Bäumker, ed., Des Alfred von Sareshel (Alfredus anglicus) Schrift De motu cordis (Beiträge zur Geschichte der Philosophie [und Theologie] des Mittelalters. Texte und Untersuchungen [ = BGP[T]M hereafter] 23.1-2; Münster i. W., 1923), p. 1.

Mediaeval Studies 47 (1985) 125-67. O Pontifical Institute of Mediaeval Studies. 
activity. For Roger we have a Compotus of 1176, in which he refers to himself as iuvenis, and an astronomical table dated for the year $1178 .^{6}$ It is known, moreover, that Alexander died in 1217. Since presumably Alfred wrote his dedication while his friend was still living and since there are strong indications that the De motu cordis was his final work, ${ }^{8}$ we are able with.some degree of probability to locate Alfred's productive years within the generation 1176-1217.

Other clues suggest that Alfred spent at least part of his adult life in Spain. The toponym 'Anglicus', by which he is commonly known, indicates that he made his reputation outside of England. ${ }^{9}$ Furthermore, in his commentary on Aristotle's Metheora Alfred reveals the name of his master, Salomon Avenraza, 'a Jew of great renown'.10 Although Avenraza, or Ibn Ezra, has not been positively identified, the most congenial atmosphere for a Jewish scholar in the twelfth century $y_{s}$ was Spain. ${ }^{11}$

The final and most telling indication of Alfred's Spanish residency, however, is provided by the occurrence of Castilian vernacular terms in two of Alfred's Latin translations: beleño (Latinized to belenum) to render the Arabic for henbane ${ }^{12}$ and arrova (Latinized to arenorum) for a unit of weight. ${ }^{13}$ Add to the accumulated evidence the fact not only that Alfred was translating from the Arabic but also that many of his sources were unavailable elsewhere in Latin Europe at that time, and one is led to suspect the Spanish city of Toledo as the locus of his activity.

\footnotetext{
6 Haskins, Mediaeval Science, p. 125. On the significance of the designation 'iuvenis' see Wingate, Mediaeval Latin Versions, p. 98 n. 8.

7 Alexandri Neckam De naturis rerum libri duo ..., ed. T. Wright (RS 34; London, 1863), p. xii.

- The De motu cordis is certainly later than Alfred's translation of the De plantis, which it cites, and its wider use of the Aristotelian corpus and other works suggests a date later in his writing career; cf. Wingate, Mediaeval Latin Versions, p. 66, and C. Bäumker, Die Stellung des Alfred von Sareshel (Alfredus Anglicus) und seiner Schrift De motu cordis in der Wissenschaft des beginnenden xII. Jahrhunderts (Sitzungsberichte der Königlich Bayerischen Akademie d. Wissenschaften, Philos.-philol. u. hist. Klasse 9: Munich, 1913), pp. 26-48.

9 Cf., e.g., Bartholomaeus Anglicus, Petrus Lombardus, Hermannus Alemannus, Willielmus Flemingus, etc.

10 '... magister meus Salomon Avenraza, et Israelita celeberrimus, et modernorum philosophorum praecipuus', In IV libros Metheororum Aristotelis III, cap. de yride; ed. J. K. Otte in Alfred of Sareshel's Commentary on the Metheora of Aristotle (Diss. University of Southern California, 1969), p. 71.

11 See, e.g., G. Vajda, Introduction à la pensée juive du moyen àge (Paris, 1947), pp. 119-45.

12 De plantis 1.17 (Meyer ed., p. 23). Bacon cites this as 'one of a million examples' of the ignorance that translators had of Latin and admits to his having been laughed at by his Spanish students for not having understood the word when lecturing on the De plantis at Paris (Opus maius 3.1, ed. J. H. Bridges, 1 [Oxford, 1897], p. 67).

${ }^{13}$ A vicennae De congelatione et conglutinatione lapidum, ed. E. J. Holmyard and D. C. Mandevillể (Paris, 1927), p. 47. Cf. Otte, Alfred of Sareshel's Commentary, p. 139 n. 36 for variant readings.
} 
Less convincing is the attempt to connect Alfred, with the studium at Hereford. On the strength of five appearances of the name Alfred in documents relating to Hereford" between the years 1153/55 and 1207, Josiah Cox Russell has argued that; given the rarity of the name, it is 'highly probable' that one or more of the 'Alfreds' be identical with our commentator. ${ }^{14}$ This argument on closer inspection, however, turns out to be self-defeating. While on the one hand it is highly improbable that all five 'Alfreds', spread over the course of a half century, refer to the same person, on the other hand multiple 'Alfreds' militate against the claim that the name is rare. ${ }^{15}$

More promising, however, is Russell's discovery of a charter of about 1220 , in which 'Magister Alueredus de Sarutehill canonicus Lich' appears as a witness. ${ }^{16}$ Both the appropriateness of the date and the similarity between Sarutehill and any of the protean versions of Sareshel ${ }^{17}$ make it reasonable to identify the canon of Lichfield with our author.

It is, however, upon his literary output that Alfred's reputation rests, and here we are on firmer footing. Although the list of works ascribed to our author by the early bibliographers was somewhat inflated owing to a confusion with two other Alfreds (one the Anglo-Saxon king and the other a thirteenth-century papal legate ${ }^{18}$ ), we can with confidence assign to him the following titles: a translation of Avicenna's De congelatione et conglutinatione lapidum (also called De mineralibus); ${ }^{19}$ a translation of the putatively Aristotelian De plantis; ${ }^{20}$

14 J. C. Russell, 'Hereford and Arabic Science in England about 1175-1200', Isis 18 (1932) 19 (rpt. in his Twelfth Century Studies [New York, 1978], pp. 142-54).

15 Cf. J. K. Otte, 'The Life and Writings of Alfredus Anglicus', Viator 3 (1972) 282. Callus ventures the supposition that Alfred's glosses (on the De generatione et corruptione, the Metheora, and the De plantis) might represent his lectures at,Oxford but admits that thus far not the slightest clue has come to light to support such an opinion ('Aristotelian Learning', 11).

${ }_{16}$ J. C. Russell, Dictionary of Writers of Thirteenth Century England (London, 1936), p. 19. Cf. Otte, ibid., 282-83.

17 Alfred"s surname is found in manuscripts as Sarchel, Sareshel, Sareschel, Sereshel, Sarhelle, Sarewel, Sarewell, etc.; see Wingate, Mediaeval Latin Versions, p. 98 n. 7, and G. Lacombe, 'Alfredus Anglicus in Metheora' in Aus der Geisteswelt des Mittelalters. Studien und Texte Martin Grabmann Vollendung des 60. Lebensjahres von Freunden und Schülern gewidmet, ed. A. Lang-J. Lechner-M. Schmaus (BGP[T]M Suppl. 3.1; Münster i. W., 1935), p. $143 \mathrm{n}$. 2. The most irregular variant I have seen is 'Chorel' (Florence, Biblioteca Laurenziana S. Croce $13 \mathrm{sin}$. 5, fol. 163r). The surname has been variously (and inconclusively) identified with the old English surname Sarewell (Wingate, p. 99 n. 10), the village of Shareshull in Staffordshire (Russell, ibid., p. 19), and even the village of Sarceaux in Normandy (B. Hemmerdinger, 'Le De plantis, de Nicolas de Damas à Planude', Philologus 111 [1967] 59).

18 For the details see Wingate, ibid., pp. 56-58. Cf. the list of works in C. Jourdain, Recherches critiques sur l'àge et sur l'origine des traductions latines d'Aristote, new edition (Paris, 1843), p. 105.

19 See n. 13 above. The De mineralibus is an excerpt from Avicenna's encyclopedic Shifä'.

${ }^{20}$ See n. 4 above. 
a commentary on Aristotle's Metheora, to which the De mineralibus was appended as the final three chapters, ${ }^{21}$ a commentary on the De plantis; and finally an original treatise entitled De motu cordis. ${ }^{22}$ A reference in his commentary on the Metheora insinuates that he also wrote a commentary on the De generatione et corruptione, ${ }^{23}$ which apparently has not survived. Of the extant works all have been edited except for the commentary on the De plantis, which appears here for the first time.

The order of the above listing, moreover, suggests the probable order of composition. We can suppose that the commentary on the Metheora was written after his two translations, since they are both cited in the former. ${ }^{24}$ Moreover, Alfred's allusion in the same commentary to his glosses on the $D e$ generatione et corruptione, as mentioned above, indicates that the latter was composed first, and perhaps represents his earliest effort at explaining the science of Aristotle. In addition, the citation of the De congelatione in the commentary edited below ${ }^{25}$ indicates as well that the latter was composed subsequently.

For the later commentaries and the De motu cordis there are no clear internal references one to another that might aid in the dating, although the several citations of the Metheora in the commentary on De plantis hint at the fact that this commentary was written after the commentary on the Metheora. Finally, as Wingate has argued, the wider use of Aristotelian and other works in the De motu cordis makes it natural to suppose that it represents Alfred's most mature product. ${ }^{26}$

We can thus on the available evidence tentatively reconstruct the following vita for Alfred: born in England toward the middle of the twelfth century, studied in Spain under a learned Jew, with whose help he translated the De congelatis and De plantis from the Arabic, then wrote commentaries on at least three 'Aristotelian' treatises, returned to his homeland in the first or second decade of the thirteenth century and, following the writing of his own contribution to the science of his day, the De motu cordis, retired to Lichfield as a prebendary.

${ }^{21}$ See n. 10 above.

22 See n. 5 'above.

23 'Quare autem vapor et calor invisibilis flammam visibilem producant, in libro De generatione et corruptione discussimus' (Comm. in Metheora 3 [Otte ed., p. 65]). For additional evidence see Lacombe, 'Alfredus Anglićus', 464-65, and Otte, 'Life and Writings', 285-86.

${ }^{4}$ Comm. in Meth. 1, 2, 3 (Otte ed., pp. 55, 57, 60, 68).

${ }^{25}$ See p. 148 (1. 39). Holmyard and Mandeville give a date for the De congelatis of c. 1200 , "with the proviso that it may have been two or three decades earlier or, less probably, a few years later' (p. 10).

${ }^{26}$ Wingate, Mediaeval Latin Versions, p. 66. Otte, 'Life and Writings', 291 suggests a date of c. 1200 for the composition of De motu cordis, thereby pushing back the composition of his commentaries to 1190-1200 - a decade earlier than my suggested dating. 
Alfred's literary production that received the widest circulation, as judged by the number of extant manuscripts, is his translation of the De plantis, a treatise whose transmission one scholar declared to be of greater interest than its content. ${ }^{27}$ Until the sixteenth century the work was universally ascribed to Aristotle, ${ }^{28}$ although more perspicacious commentators, like Albert the Great, were troubled by its repetitiousness, its insipidity, and even its occasional contradictoriness. ${ }^{29}$ Finally, with the publication of his edition of the work in 1841, Ernst Meyer was able to offer conclusive evidence of the authorship of Nicholas of Damascus, a peripatetic who spent his life in the service of Herod the Great, king of Judea. ${ }^{30}$

Subsequent scholarship has established that the original Greek version, now lost, was rendered into Syriac in the ninth century, ${ }^{31}$ and thence into Arabic by Ishaq ibn Hunain in about $900 .^{32}$ Alfred made his Latin translation before the year $1200,{ }^{33}$ and Roger Bacon testified to the existence of a second Latin version in the first half of the thirteenth century. ${ }^{34}$ Alfred's version proved immensely influential, as the survival of approximately 170 manuscript copies bears witness, ${ }^{35}$ and by 1254 was prescribed by the Arts faculty at Paris as a subject of examination. ${ }^{36}$ To complete the cycle, the Latin De plantis was translated back

${ }^{27}$ Hemmerdinger, 'Le De plantis', 65.

28 Julius Caesar Scaliger was the first to demonstrate conclusively that the author of the De plantis was not Aristotle, heading the preface to his commentary on the work (published in 1556) In libros De plantis falso Aristoteli attributos (J. Longrigg. 'Nicholas of Damascus', DSB 10 [1974] 112). There remains the possibility that Aristotle did compose a $\Pi_{\varepsilon \rho i} \varphi v \tau \bar{\omega} v$ : Diogenes Laertius credits him with a work by that title and there are multiple references to such a work in the authentic treatises; see G. Senn, 'Hat Aristoteles eine selbständige Schrift über Pflanzen verfasst?', Philologus 85.2 (1930) 113-35.

29 Albert attributed the inferior quality of the text to the ignorance of translators, who failed to understand either the mind of the Philosopher or the language from which they were translating (De vegetabilibus libri VII 1.1.9, ed. E. Meyer and K. Jessen [Berlin, 1867], p. 32).

${ }^{30}$ Meyer, De plantis, pp. xii-xxv. For Nicholas see DSB 10.111-12.

10.111).

${ }^{32}$ Hemmerdinger, 'Le De plantis', 58. A badly preserved copy of the Arabic version, lacking several chapters at the end, was discovered by M. Bouyges in 1923 and has been catalogued as Istanbul, Yeni Cami ms. arab. 1179 ('Notes sur les philosophes arabes connus des latins au moyen age', Melanges de l'Université Saint-Joseph Beyrouth 9.2 [1924] 78). It was first edited by A. J. Arberry, 'An Early Arabic Translation from the Greek', Bulletin of the Faculty of Arts, University of Egypt 1.1 (1933) 48-76.

${ }^{33}$ Wingate, Mediaeval Latin Versions, p. 59. Otte dates it to the decade 1180-90 ('Life and Writings', 291).

${ }^{34}$ Wingate, ibid., pp. 62-64.

${ }^{36}$ L. Minio-Paluello, Opuscula: The Latin Aristotle (Amsterdam, 1972), p. 528. col. 278 . 
into Greek by Maximus Planudes later in the century, and it was this version that was eventually printed in the Bekker edition of Aristotle's works. ${ }^{37}$

Alfred's commentary on the De plantis is the earliest and probably briefest of the nine or more composed during the medieval period. ${ }^{38}$ The date of composition, as we have seen, is certainly later than his translation of De plantis and probably also later than his commentary on the Metheora, yet probably earlier than the De motu cordis. Wingate, in assigning the De plantis commentary to the lustrum 1210-15, argues that the work must postdate the Arabic-Latin version of the De animalibus by Michael Scot, which she says Alfred utilizes. ${ }^{39}$ The paraphrase in Alfred's commentary, however, is so loose that one cannot with any degree of certitude conclude that the version is Michael's. ${ }^{40} \mathrm{I}$ prefer the decade $1200-10$ as a tentative date of composition for the commentary edited below; this dating allows sufficient time on the one hand for the dissemination of the Aristotelian treatises he cites and on the other for the composition of his final work, for which I accept the terminus ante quem of 1217.

Taking the form of a gloss, extending at times for a paragraph or more, on sixty-two words or phrases drawn from the first four chapters of the first book of the treatise and the final ten chapters of the second and last book, the commentary is notably shorter than the treatise being commented upon. Why Alfred chose not to gloss the middle twenty-two chapters of the work, approximately two thirds of the whole, is not known. The simplest explanation is that he did not find them that interesting or worthy of comment. Yet the omitted chapters do contain several provocative issues, as Roger Bacon and Adam of Buckfield were soon to discover: for example, the notion of homologous organs, the case of plants that change their species in the course bf their development, the fact that certain kinds of logs float while other kinds sink, and so forth.

Commenting on the opening words of the De plantis 'Life is found in animals and plants', Alfred distinguishes in the lower world (that is, in the substances inferior to man) four primary genera: indistinct substances (confusa), solidified substances (congelata), plants, and animals. The indistinct substances (confusa),

${ }^{37}$ DSB 10.112.

38 C. H. Lohr documents the existence of nine such commentaries: 'Medieval Latin Aristotle Commentaries', Traditio 23 (1967) 323, 343, 355, 388; 24 (1968) 152, 227-28; 26 (1970) 160; 28 (1972) $342 ; 29$ (1973) 120. There is, in addition, an anonymous commentary in Cambridge, Peterhquse ms. 157, which has not been identified with any of those listed by Lohr.

${ }^{39}$ Wingate, Mediaeval Latin Versions, pp. 59, 65, 76. She gives 1210 as the terminus ante quem of Michael's translation (p. 65), while T. Struve says it was 'toward 1220' ('Die Anthropologie des Alfredus Anglicus in ihrer Stellung zwischen Platonismus und Aristotelismus', Archiv für Kulturgeschichte 55 [1973] 368).

${ }^{40}$ Otte, 'Life and Writings', 286-87. Michael's text is reproduced in Wingate, ibid., p. 76. 
he explains, are commonly called the elements, though in reality they are composed of mixtures of the elements or what he later refers to as elementata. ${ }^{41}$ In other words, the four elements of Greek science as found in nature are in fact deformed combinations of several elements (earth also containing water and air, water containing earth and air, and so forth), while yet retaining the trăces of the dominant element: ${ }^{42}$

By the congelata he means a whole class of metallic and non-metallic compounds which are formed by solidification. Alfred had used the term in his translation of a part of Avicenna's Shifä', entitled De mineralibus; stones, Avicenna explains, are formed in two ways: either by the conversion of clay into a hard, porous substance when heated (the process of pottery making), a process which Alfred calls conglutinatio; or by the depositing of sollids from water, interpreted by Avicenna as a solidification of water itself, which Alfred translates as congelatio. ${ }^{43}$ The 'congealed' substances are receptive to generation' and increase, but not to sensation and growth. The plant, on the other hand, when sustained by its root, both reproduces and grows. Thus, Alfred calls the plant an 'animate, insensible substancê'. 44

Only in the final two genera.is life to be found. Whereas in thễ animal the signs of life are quite manifest, however, in the plant vital effects are -few, whence life in the latter is said to be hidden. One can, in fact, scarcely discern the difference between plants and minerals:- For even inorganic' substances suffer augmentation and diminution and thus seem almost to be 'growing. ${ }^{45}$

'A long inquiry must be held', continues the pseudo-Aristotelian text, 'as to whether plants possess a soul and a distinguishing capacity for desire and pleasure'. The opinion of Anaxagoras, explains Alfred, was that trees were much saddened both by the" loss of 'solar time' (that is, the' shortening of daylight hours) and by the loss of their flora, fruit, and sap. The fact that trees lose their leaves in the fall of the year is evidence of this sadness. ${ }^{46}$

${ }^{41}$ See T. Silverstein, 'Elementatum: Its Appearance among the Twelfth-Century Cosmogonists', Mediaeval Studies 16.(1954) 156-62.

12 See below, pp. 145-46 (1l. 3-6).

${ }^{43}$ See Avicennae De congelatione (Holmyard and Mandeville ed., p. $18 \mathrm{nn} .4$ and 5). congelata for the Saracens included quicksilver, sulphur, and all metals (Haskins, Mediaeval Science, p. 94).

44 p. 146 (11. 9-10).

45 ibid. (11. 12-21). Cf. Albert: 'Operationes autem eius similiter sunt trahere alimentum et augere et generare, quibus per aliquem modum videntur communicare corpora physica inanimata et "non viva. Illa enim generantur, et quantitates accipiunt; et cum quantitas non accipiatur sine aliquo attracto quod in substantiam convertitur, videntur, quod haec etiam alimentum accipiant' (De vegetabilibus 1.1.2 [Meyer and Jessen ed., p. 6]).

46 p. 147 (11. 24-26). Meyer incorrectly reads 'flexum foliorum' (see below, p. 147); the,gloss, however, makes it clear that Alfred"wrote 'fluxum'. Cf. A. J. Arberry, "Notes on The Book of Plants, Part I', Bulletin of the Faculty of Arts, University of Egypt 1.2 (1933) 220. 
Plato calls 'desire' the attractive, retentive, and digestive power of the plant. But Aristotle, Alfred notes; polishes that truth in disputation and determines that plants possess souls, which distinguishes them from the congelata. 'For plants are born, grow, and develop according to the conditions of the seasons; they also die of old age - all of which plants have in common with animals.' 47

Do plants experience hunger? The pangs we call hunger; 'explains Alfred, are felt only in the stomach. The os stomachi or cardia ${ }^{48}$ must first sense the attracting force on the part of the members of the body and be saddened by the prick of this appetite, so that it may be gladdened by the food to come. Both the hunger and the subsequent gratification are experienced through the medium of the senses. For the animal senses an emptiness, whence it is irritated, and understands what it must do to relieve this emptiness, whence the pain is removed. Thus desire, including the specific desire called hunger, presupposes sensation. Plants lack sensation, argues Alfred, and hence lack desire. He calls Plato's opinion, to the contrary 'remarkable' (mirabilis). ${ }^{49}$

Following, a brief and seemingly misplaced discussion on the three basic species of vapor and the compatibility of each with a life form, ${ }^{50}$ Alfred comments on the text 'Desire can only proceed from sensation'. Plants neither have specific organs designed for sensation nor do they possess nerves, which are-the instruments of sensation; the plant, says Alfred, is in fact denser than eyen the nervi duri, which are the motor nerves in the animal. ${ }^{51}$ Furthermore, nature and the Creator designed the plant in such a way that it is able to function quite fully without sensation, without even the sense of touch. Thus the power of sensation in the plant would be superfluous and, as we know from the Aristotelian aphorism, nature does nothing in vain. ${ }^{52}$ If, as the text says, 'Sensation is the cause of the glorification of life', then life without sensation holds the semblance of death. The power of sensation, on the other hand, soon draws life into activity..$^{53}$

47 pp. 147-48 (11. 30-36).

48 i.e., the upper orifice where the esophagus enters. For the analogy between the stomach of the animal and the roots of the plant see Aristotle, De longaevitate vitae 6 (467b4-5).

49 pp. 148-49 (11. 44-52). Albert finds Plato's view more tolerable than the views of Anaxagoras or Protagoras (which appears in the text in its corrupt form 'Abrutalis'/'Abrucalis'), in that he assigns only desire to plants, and not sensation nor sex (De vegetabilibus 1.1.2 [Meyer and Jessen ed., p. 8]).

so Cf. the discussion in Alfred's Comm. in Metheora 1 (Otte ed., p. 46).

st Galen distinguished between the hard nerves, which directed movement in the animal body, and the soft nerves, which conveyed sensory impulses; see E. Nordenskiöld, History of Biology (New York, 1949), pp. 62-63. Cf. De motu cordis 2 (Bäumker ed., p. 11).

52 pp. 150-51 (11. 78-91). Roger Bacon invokes the same principle (that is, natura nihil frustra) in determining the question whether plants possess the sense of touch (Quaestiones supra De plantis, ed. R. Steele and F. Delorme in Opera hactenus inedita 11 [Oxford, 1932], pp. 186-87).

53 p. 151 (11. 103-104). In De motu cordis 10 Alfred repeats the expression: 'Primus enim et praecipuus sensuum et quo mediante alii ducuntur ad actum ... tactus est' (Bäumker ed., p. 43). 
Sexual reproduction also presupposes sensation, since the animal would not desire coitus unless it took delight therein. This is why the plant reproduces solely by dissemination, that is, by the scattering of its seed. Since, however, there is no mean between the animate and the inanimate, and since, as Alfred has demonstrated, the plant cannot be inanimate, it should be termed 'animate .non-living' (animata non uiuens). ${ }^{54}$

The lines of demarcation between the various genera, as Aristotle knew (anid the contemporary biologist would concur), are not always clear and distinct. Clams. and oysters, for example, seemed to the pseudo-Aristotle a fatal exception to the generalization that no plant possesses sensation, inasmuch as the lack of the discriminating power to utilize this luxury renders it superfluous. Alfred here is implying that mollusks, since they lack any power to discriminate, should by the law of natural economy also lack the power to sense. Conversely, if mollusks sense, so too do plants. ${ }^{55}$

Alfred responds to the objection by insisting that mollusks do possess the power of discernment in some fashion or other, since we find them opening and closing their shells at will, even though they do not propel themselves from place to place. Sensation therefore remains the sole specifying difference between the plant and animal kingdoms. ${ }^{36}$ In addition, the power of selfmovement, or voluntary movement, would be superfluous in the plant, since it lacks the power to sense. The immobility of the plant in other words is a corollary of its insensibility. ${ }^{57}$

Alfred's gloss on the text 'This is the acquisition of life' is obscure, and it is likely that the passage is corrupt. ${ }^{58}$ Life, he says, is both a substantial and distinguishing or specifying component, but its absence is not considered a characteristic that constitutes a species (specifica). His meaning thus far can be grasped; it is the reason that follows that is elusive: 'because', Alfred continues, 'at the bidding of the Creator every celestial animal (with respect to the absence of life) is associated with (or belongs to the same set as) one composed of the elements, out of a defect namely of nature, just as some species posits that "biped" is a property of man and "mortal" part of his definition, although improperly." 39

34 p. 152 (11. 109-113).

35 pp. 152-53 (11. 114-122).

so p. 153 (11. 123-126). Note the parallel text from Avicenna's Liber sextus in the fontes (note to 1.125 below). Cf. also Bacon, who cites the same Avicennian text (Quaestiones [Steele and Delorme ed., p. 187]).

${ }^{57}$ p. 153 (11. 126-128).

si Interestingly, although Adam of Buckfield depends heavily on Alfred's commentary, he does not cite this text.

59 p. 154 (11. 142-146). See Aristotle for the latter example: Prior Analytics 1.31 (46b2-25) and Posterior Analytics 2.5 (92al-6). The Durham manuscript (D below) treats elementatum as a lemma (which it is not), and this gives some indication of the scribe's confusion over the passage. 
To arrive at a definition by process of differentiation according to Aristotle is illegitimate if the opposites do not exclude a middle. ${ }^{60}$ Alfred seems to be inferring in his example of the heavenly bodies that there is a middle between animal or animated substance and inanimate substance, namely, non-living animated substance, which identifies both the heavens and the plant kingdom. In his commentary on the Metheora, for example, he takes note of Plato's fourfold division of animal genera: celestial, airy, watery, and earthy, but adds that 'animal' is predicated of them equivocally. Celestial and airy substances are not natural (or are 'defective by nature'), because they lack the power of sense perception, ${ }^{61}$ which alone identifies life in its fullest sense. In like manner, it is improper to include mortality, which implies a loss of life, in the definition of man, because it is not sufficiently exhaustive and no more defines man than does 'biped'.

The vegetable soul, furthermore, is boundless and indeterminate with respect to its function, since a tree never has so many branches that it cannot sprout more. In this respect it resembles the rational soul, in that the soul or mind cannot comprehend so many things that it cannot know more. It also resembles the animal soul, in that the powers of sensing and imagining are boundless. ${ }^{62}$

Leaving unglossed the following twenty-two chapters Alfred next turns his attention to book 2, chapter 7, where he discusses 'hot' and 'cold' plants and the climatic conditions which generate these qualities in them. Only those plants are edible which are of subtle and digestible material and already fully dissolved or digested by heat and moisture. ${ }^{63}$

Owing to the abundance of temperate air and moisture in hilly regions, moreover, plants growing there are often found to be sturdier and more fertile than those growing in valleys, where the air is putrefying and the vapors gross. The latter conditions give rise to irregular digestion on the part of the plant, which in turn produces humor that is briny. ${ }^{64}$

60 Posterior Analytics 2.13 (97a18-22).

61 'Notat Plato IIII ${ }^{\circ}$ esse animalium genera: commemorat celeste, aereum, aquaticum, terreum. Set sciendum est animal de eis equivoce predicari. Celesté enim et aereum naturalia non

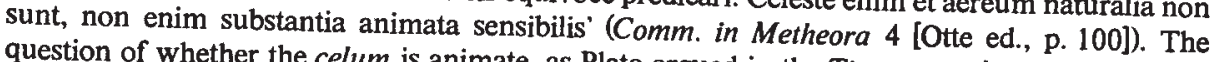
Alfred and his contemporaries, who were, as Plato argued in the Timaeus, was a vexed one for the idea is the text of the the idea is the text of the Physics which says that self-motion is animal motion; against is the to the celum as an animal (below body lacks sense perception. Bacon defends Aristotle's referring but that of others (Qual (below, p. 154) by claiming that he is here not giving his own opinion, intentio instead of inuentio and interprets the ed., p. 190]). Albert, on the other hand, reads 'intensification of life' but is not interprets the passage to mean that sensation constitutes the coelo' (De vegetabilibus is not shared by all living things, 'sicut patuit in exemplo inducto de

${ }^{62}$ p. 155 (11. 147-152).

${ }^{63}$ p. 156 (11. 171-173).

64 ibid. (11. 175-181). 
For a plant to be durable, continues Alfred, it must have a well-digested and oily humor. Plants with a watery and undigested humor quickly dry out with the coming of the cold. For this reason a stalk (caulis) does not last beyond three years, unless it be grafted onto another ${ }^{65}$ While Alfred is silent on the philosophical difficulties raised by the process of grafting, they do not go unnoticed by Roger Bacon. In his lectures on the De plantis Bacon worries at length over the question of whether the graft retains its original soul or participates in the life-principle of the host plant, whether the graft changes its species if joined to a host of a different species, and so forth. ${ }^{66}$

The growth of plant life, maintains our commentator, is best served by a temperate climate. An overabundance of humidity will force open the ducts (that is, the vascular system) through which normally nutriment rises in the form of smoke or vapor, with the result that the nutriment is forced downward and the' plant is not nourished. Too much dryness, on the other hand, constricts the ducts, again preventing the nutriment from rising. ${ }^{67}$

Every plant has four needs, Alfred declares: a definite seed, complete in its kind, fully ripe, and preserved from putrefaction; a suitable place (these first two being necessary for the plant's generation); moderate moisture; and a temperate climate (these last two necessary for the plant's nutrition and growth). ${ }^{68}$

The farther removed a place is from the sun, the longer the day is in the summer. In the far North plants enjoy daylight for half the year, darkness for the other'half. Thus it is rare that any plant or animal is born or grows there, for ' in the summer they have to contend with the continuous heat and in the winter with the continuous cold. ${ }^{69}$

In succeeding sections Alfred explains why olive trees bear fruit only biennially (owing to their viscosity they attract little moisture) and the cause of thorns in certain plants (viscous humor is obstructed in its upward path and breaks out laterally in a pyramidal shape). ${ }^{70}$

Glossing the text 'Greenness must be the most common characteristic of plant life', Alfred hazards an explanation of why this is so. In every life-form that draws its nutriment from the earth there is present in dominant measure the earthy humor. Now the color of this humor, since it has an admixture of moisture and heat (though the latter only minimally), is green. That the earthy

\footnotetext{
65 ibid. (11. 182-187).

${ }^{66}$ Quaestiones (Steele and Delorme ed., pp. 244-51).

${ }^{67}$ p. 157 (II. 188-193).

6s ibid. (11. 194-202).

${ }^{69}$ pp. 157-58 (Il. 203-207).

70 p. 158 (11. 208-216).
} 
humor predominates, moreover, is evident because the desiccated cortex turns black. In some leaves, however, there is a greater percentage of moisture and a correspondingly smaller percentage of the earthy element; this means that their green will be less intense. Indeed we note that when such leaves dry out they turn yellow. ${ }^{11}$

The text 'The shapes of plants' occasions a discussion of the reasons why certain plants tend to grow upward, while others tend to grow downward. Again it is a question of which humor/element predominates. Some, like the ash (fraxinus excelsior) and the fir (probably abies alba ${ }^{72}$ ), both of which have a large measure of the airy element and an ample and direct vascular system (pori), grow to a great height. The prevalence of the airy element in the fir tree, adds Alfred, also accounts for its lightness and softness. Others, in which the watery element is dominant, tend to grow downward. Finally, the medlar (mespilus germanica ${ }^{73}$ ) is cited as an example of a well-balanced tree, in that it grows in both directions equally well. ${ }^{74}$

In the plant there are but two digestions: in the root $^{75}$ and in the pith (medulla). This is so because the substance of the plant is gross and not far removed from the elements or from its own nutriment. In the animal body, on the other hand, there is a great diversity of members, and given that these members are distant in nature from their nutriment, there is need for many mutations and a manifold digestive process. ${ }^{76}$

The shape of the plant results from the size and perfection of its seed; if the seed be imperfect, so too will be the resulting plant. The blossoms and the fruit, on the other hand, respond to the nutriment from which they are produced. Alfred mistakenly notes a difference between animal and.vegetable seed: animal sperm contains both a part that will develop into a fetus and a part that is nutriment, which he illustrates by the yolk and albumen of an egg; vegetable

71 pp. 158-59 (11. 217-225).

72 The medieval nomenclature of conifers is puzzling and inconsistent, and the abies is now placed under three different genera; see Jerry Stannard, 'Identification of the Plants Described by Albertus Magnus, De vegetabilibus, lib. VI, Res publica litterarum 2 (1979) 284.

${ }^{73}$ See Albert: 'Mespilus est arbor nota, quae alio nomine esculus corrupte vocatur' (De vegetabilibus 6.133 [Meyer and Jessen ed., p. 405]). Cf. Stannard, ibid., 302.

74 pp. 159-60 (11. 228-235).

75 The text reads in planta, but Alfred surely intended in radice (as below, p. 163). Cf. also De motu cordis 14: 'In simpliciter autem vegetabilibus duae tantum celebrantur digestiones, una scilicet in radicibus, altera in corpore et ramis, quae epatis vicem tenent' (Bäumker ed., p. 74). Adam of Buckfield also has in radice (Vatican Library Vat. lat. 5988, fol. 17v). Alfred is here at variance with his text (below, note to 1.236 ), which says that the first digestion takes place in the earth below the roots before the nutritive matter is absorbed. This is also hqw Albert interprets the text (De vegetabilibus 4.3.5 [Meyer and Jessen ed., pp. 270-71]).

${ }^{76}$ p. 160 (11. 236-241). 
seed, however, does not germinate unless it has first drawn nutriment from without. ${ }^{n}$

The plant continues to grow in height until the ascent and circulation of moisture is impeded either by an excess of moisture or cold, or by hardness or some other constriction. Once this passage is impeded, the plant begins to dry out and ceases to live. The animal, Alfred says, generally does not grow vertically to the extent that the plant does, nor does the former have the free exit at its terminus as does the latter; in other words, humors do not escape through the head of the animal, as they do through the leaves of a tree, but are there retained and recycled. In addition, new members are not continuously generated in the animal body, as they are in the plant, owing to the diversity of matter in the former: bone and nerve can be generated only from the first matter of the animal. ${ }^{78}$

Trees with viscous humors retain their leaves, while those with watery humors shed theirs. Whether a species of plant bears fruit once a year or repeatedly, moreover, depends on the strength of its power of attraction: the strongest attractive force, upon which depends a perfect digestion, results in but a single crop of fruit. ${ }^{79}$

Alfred distinguishes four genera of plants: trees, bushes, herbs, and vegetables. In the latter two genera moisture so abounds that their matter does not solidify, as opposed to trees and bushes. Whence it happens with herbs that following a season of ripening ${ }^{80}$ their moisture is driven back with the onset of cold weather and they wither; and thus vegetables do not last beyond the third year. ${ }^{81}$

Commenting on the word 'blueness', a word for which scribes of both the De plantis and the commentary thereon have provided more variant readings than for any other, ${ }^{82}$ Alfred attributes the presence of the color in the tree to the effect of the action of heat in the digestive process. The core of the wood, 'heartwood' in contemporary terminology, is as black as ebony, and the rest ranges in color from black to the increasingly whiter color of the "sapwood" according to the intensity of heat generated from the ininer to the outer rings of the tree. ${ }^{83}$ Another factor affecting color is the proportion of the earthy and

$"$ pp. 160-61 (11. 242-253).

78 p. 161 (Il. 254-266).

79 pp. 161-62 (11. 267-271).

${ }^{80}$ See Appendix A.

p. 162 (11. 272-275).

32 See Appendix B.

Albert, whose copy text reads ventalitas, interprets the range of colors to apply to different species of trees, with the ebony and the elm as extremes of black and white respectively. However, Albert admits with obvious frustration that this opinion of Aristotle 'propter malitiam translationis vix est intelligibilis' (De vegetabilibus 4.4.1 (Meyer and Jessen ed., p. 277]). 
watery elements in the tree. A preponderance of earth produces black, of water white, and a balance between the two a yellow color in the wood. ${ }^{84}$

Some trees, like the fig (ficus carica), have gross and viscous humors, and, because such humors cannot be thinned, trees of this sort produce no flowers. Others, like the palm (phoenix dactylifera), have humors that are so watery that they cannot be digested and for that reason lack flowers. Trees with a thick and hard bark tend to grow tall rather than spread laterally, because the heat on the outside is not able to attract the nutriment sideways. ${ }^{85}$

The milky substance called latex (lac) is produced in certain species of plants in the following way: the first digestion, which takes place in the root, is heavy (fortis), so that the humor becomes oily and, when 'cooked' a second time in the pith, is transformed into latex. In the summer this latex resists solidification or coagulation owing to the heat, which, 'entrapped in its stickiness', keeps the latex molten. With the coming of cold weather, however, the latex solidifies completely. Similarly, if the latex should break out, it would solidify in the intense heat of the surrounding air. Wherefore gum (gummi), which is sticky latex or resin, is solidified either by intense heat or by intense cold; moderate heat, on the other hand, has a liquefying effect on the latex. ${ }^{86}$

Gums, Alfred continues, ooze in temperate air, but do not coagulate. He adds that his author seems to be saying in the preceding chapter that gum is never solidified by the cold, unless it be of a milky and sticky humor. Even a liquid humor is solidified by heat, however, if the heat is intense enough. ${ }^{87}$

Some trees, like the boxtree (buxus sempervirens), is green in summer, yellow in winter, because, although the tree itself has a rather viscous humor, the root system has much clear moisture; and therefore the boxtree does not lose its leaves. With the advent of warm weather the humor is drawn to the surface and the tree becomes green; the coming of the cold repels the humor, and the tree as a consequence becomes drier, resulting in turn in its color becoming yellow.

Likewise, fruit at the beginning of the growing season is bitter owing to the cold. And although the taste of such fruit is commonly called sour (acidus),

${ }^{84}$ pp. 162-63 (ll. 276-284).

8 p. 163 (11. 285-292).

${ }^{86}$ pp. 163-64 (11. 293-300). Albert's commentary is considerably more illuminating here than Alfred's, which differs from the text only in some details. The heat generated by the digestive process of the tree, says Albert, is insufficient to separate the latex into its three constitutive substances: the watery, buttery, and cheesy (analogous to mammalian milk), but does consume excess moisture, thus producing a viscous substance. When extracted from the tree, however, the coldness of the surrounding air turns the latex into gum (De vegetabilibus 4.4.2 [Meyer and Jessen ed., pp. 280-81]).

${ }^{37}$ p. 164 (11. 301-306). Adam distinguishes four kinds of gums, each reacting differently to heat and cold (Vat. lat. 5988, fol. 19r). 
there is this difference: if coldness and dryness combine with a substance that is gross, the resultant taste will be briny (ponticus); if with a clear and subtle substance, the taste will be sour or bitter. A perfect digestion, on the other hand, which requires heat and moisture, will produce a sweet-tasting fruit. ${ }^{88}$

Paradoxically, trees that grow in sour water produce fruit that is sweet. Following closely the reasorling of his text, Alfred says that the sourness draws into the tree a sour humor, which is cold and dry. The less digested portion of this humor the tree emits as fruit and foliage. But the fruit, at first bitter, becomes sweet as it is further digested, aided by increasing heat and moisture. Because there is much heat and little moisture in such places, however, this humor is quickly consumed, and the resultant hot and dry qualities produce a sour fruit. Trees which grow in a temperate climate produce fruit before spring, because in the constantly temperate air the ducts of the vascular system will remain open and clear, and digestible humor, which can be digested with but a little heat, will be present for the production of fruit. ${ }^{89}$

Alfred concludes his commentary with a note on the myrobalan tree. ${ }^{90}$ Owing to the middling-size ducts of the tree's vascular system the path of the heat-containing humor is obstructed in hot weather. This results in a preponderance of cold and dry qualities in the fruit, which produces a briny flavor. As the hot weather grows more intense, however, the ducts will open, and hot and dry qualities will prevail, resulting in a bitter flavor. ${ }^{91}$

In his dedicatory prologue to his translation of the De plantis Alfred observes for Roger how strenuously. he had labored to render such difficult material from the free-flowing.(fluido) language of the Arabs to the contractedness of the Latin idiom and how little of his own he had added in the process. ${ }^{92}$ To comment on such a knotty text, however", to add as it were "something of his

8 pp. 164-65 (11. 307-316).

p. 165 (11. 317-325). Although Alfred's chemistry is primitive, no fruit farmer today would argue with his observations.

90 The myrobalan is a fruit, similar to a prune, from trees which grew in India; it was a very common article of trade and frequently appears in Arabic and Salernitan medical works. See $O E D$, p. 812. Albert identified five varieties of myrobalan; see Stannard, 'Identification', 302. Cf. also A. J. Arberry, 'Notes on The Book of Plants, Part II', Bulletin of the Faculty of Arts, University of Egypt 2 (1934) 104.

91 p. 166 (11. 329-339).

92 De plantis, Alfredi ad Rogerium dedicatio (Meyer ed., p. 4). Concerning this observation Adam of Buckfield 'writes: 'Significat quomodo se habuit in transferendo, dicens quod nihil apposuit de suo sed solum in transferendo angustias nostri sermonis ampliauit. Causa enim propter quam nihil adiecit in transferendo eo quod Alueredus sue scientie paruitatis conscius, excellenciam philosophie considerans, cuius hec doctrina non est parua pars, immo magna magis et essentialis, ne presumptuose uidetur egisse, nihil noui neque de proprio adiecit in transferendo' (Vat. lat. 5988, fol. 1r). 
own', proved to be an irresistible temptation for Alfred, and the tradition of commenting on the botanical science of the pseudo-Aristotle was born.

Alfred's efforts at unraveling his text, it must be conceded, were not altogether successful. Indeed, at times his gloss appears to obfuscate rather than illuminate. ${ }^{93}$ His tools of analysis are principally the traditional Greek lore regarding the four elements, already familiar to the Latin West through the pages of the Timaeus, and the cognate doctrine of the four primary qualities. Add to this an acquaintance with Aristotelian logic, at least a fragmentary knowledge of Aristotelian biology, a passing familiarity with Greco-Arabic science, especially the writings of Avicenna, and Alfred's repertoire is exhausted.

Convinced that the text he translated and was now glossing was from the pen of the Stagirite, Alfred naturally seeks support and enlightenment from other treatises in the Aristotelian corpus. Upon examination, however, these citations turn out to be paraphrases at best and wrongly attributed at worst. ${ }^{94}$ of the works he cites by name (De generatione et corruptione, De animalibus, Metheora, De anima, and the Analytica posteriora) none is referenced by book and/or chapter, and one is left with the impression that Alfred was quoting from memory, a memory that occasionally was faulty. ${ }^{95}$

Aware of the pedagogical power of examples, moreover, Alfred illustrates his commentary with several genera of trees that were either native to Western Europe or familiar through Biblical or patristic literature: the ash, the fir, the medlar, the fig, the ebony, the palm, and the boxtree. ${ }^{96}$ There is no indication in the text that any of Alfred's examples were based on personal observation, but it would not be unreasonable to assume that at least some were. We know, for example, that Albert the Great made time in his busy schedule to observe, to smell, and to taste the various plant species he came across in his travels. ${ }^{97}$

${ }^{93}$ See, e.g., his glosses on the texts 'Desiderium non est nisi ex sensu', 'Sunt autem animalia que sexu carent', and 'Et hec est inuentio uite'.

94 For wrong attributions see below, notes to $11.73,77,125$. On Alfred's use of sources in his commentary on the Metheora see J. K. Otte, 'The Role of Alfred of Sareshel (Alfredus Anglicus) and His Commentary on the Metheora in the Reacquisition of Aristotle', Viator 7 (1976) 199-206.

${ }_{95}$ The exception is the De congelatione, which Alfred had translated and which he apparently thought was authentic Aristotelian material; see below, note to 1. 39 .

96 I am grateful to Professor Jerry Stannard for identifying these names for me. Alfred's choice of trees, unfortunately, provides no evidence for a sojourn in Spain (or anywhere else); those trees which were not winter-hardy, and hence native to southern Europe, were quite common in the literature (e.g., the palm, the fig, and the ebony). See, e.g., Isidore; Etymologiae 17.7, where all of Alfred's examples are described.

97 See especially J. Stannard, 'Albertus Magnus and Medieval Herbalism' in Albertus Magnus and the Sciences. Commemorative Essays, 1980. ed. J. A. Weisheipl (Studies and Texts 49; Toronto, 1980), pp. 355-77. 
In part, the lack of clarity in Alfred's commentary can be attributed to the fact that, although he was attempting to explain Aristotelian science, he continued to think like a Platonist. The absence of direct citations in his De plantis commentary notwithstanding, the influence of Plato's Timaeus ${ }^{98}$ and Avicenna's Shifä ${ }^{\prime 99}$ is strong and pervasive. While Alfred may have read more of Aristotle's biological corpus than any of his contemporaries, he failed to grasp fully its conceptual implications and its profound differences from Platonism and the Platonic tradition. Indeed, at least-a full generation was to pass before the new science could truly be said to have been 'reçeived'. among the Latins. ${ }^{100}$

Whatever its shortcomings, however, Alfred's little tractatus was widely used in the schools for about fifty years, up until the time, in fact, when it was superseded by Albert's magisterial work. I have found five citationś of the commentały in the De proprietatibus rerum of Bartholomaeus Anglicus ${ }^{101}$ and an even more extensive use in the De plantis commentary of Adam of Buckfield. ${ }^{102}$ Grosseteste cites the work in his De natura locorum, ${ }^{103}$ and a citation appears as well in an anonymous commentary on the Physionomia ${ }^{104}$ Daniel Callus, finally, has documented its use by Roger Bacon and Henry de Renham. ${ }^{105}$

Alfred's achievement, in conclusion, must be evaluated,within the context of his age: He was on the cutting edge of a movement that was to alter irrevocably the medieval mind. But if Alfred's commentary on the De plantis heralded the birth of the science of botany in the Latin West, it must also be noted that the baby was barely out of the womb. Not until a generation later did the infant science take its first tentative steps forward.

\footnotetext{
98 See, e.g., his assigning of powers, ungrounded in a soul, to the plant, his attribution of feelings of pleasure and pain and their accompanying desires to plant life, and his reference to the heavens as animated and 'elemented'.

${ }^{99}$ See, e.g., 11. 39, 39-40, 41, 125. Bäumker has ably demonstrated Avicenna's influence on the De motu cordis ('Die Stellung', 52 et passim).

100 Callus, 'Aristotelian Learning' (n. 2 above), 4-5.

101 De proprietatibus rerum 17.2 (Paris, Bibliothèque Nationale lat. 16099, fols. 142r-151v, passim).

${ }^{102}$ Adam's use of Alfred's commentary is very extensive, incorporating a major portion of the latter's work verbatim within his own commentary. The extent of Adam's borrowing needs, however, to be more precisely documented.

${ }^{103}$ De natura locorum, ed. L. Baur in Die philosophischen Werke des Robert Grosseteste, Bischofs von Lincoln (BGP[T]M 9; Münster i. W., 1912), p. 68.

104 Rome, Biblioteca Alessandrina ms. 81, fol. 82r-v.

${ }^{105}$ Callus, 'Aristotelian Learning', 11.
} 
Although in a few instances Alfred's glosses accompany the text of the De plantis, ${ }^{106}$ they are nearly always incomplete, sometimes mixed with at least one other commentary, and often paraphrased. Since such interlinear and marginal glosses do not contribute in any significant way to the establishment of the text, I have based this edition only on those manuscripts that transmit the commentary as an independent work. The following are the nine that have been identified and their sigla: ${ }^{107}$

B = Oxford, Balliol College 105, fols. 12r-15r. ${ }^{108}$ Early 14th century; Dutch or German bookhands.

$\mathrm{C}=$ Oxford, Balliol College 112, fols. $173 \mathrm{v}-174 \mathrm{v} .{ }^{109}$ Early 14th century; English hand; manuscript breaks off, unfinished, at the words 'acidus uel amarus".

$\mathrm{D}=$ Durham, Chapter Library C.III.15, fols. $115 \mathrm{r}-116 \mathrm{v} .{ }^{110}$ Beginning of 14th century; also contains Alfred's In Metheora; corrected in accordance with a better manuscript.

$\mathrm{K}$ = Kynžvart, Zámecká knihovna $22 \mathrm{D}$ 2, fols. $248 \mathrm{v}-250 \mathrm{v} .{ }^{111}$ End of 13 th century.

M = New York, Morgan Library M. 857 (formerly Adm̧ont, Stiftsbibliothek 487), fols. $77 \mathrm{v}-79 \mathrm{v} .{ }^{112}$ End of 13 th/ beginning of 14th century; no emendations.

$P=$ Paris, Bibliothèque Nationale lat. 14700, fols. $391 \mathrm{r}-394 \mathrm{v} .{ }^{113}$ "13th century; in a black, rather uncultivated hand.

106 See, e.g., New Haven, Yale University, Beinecke Library Cushing 12 (formerly Admont, Stiftsbibliothek MS. 126); Durham. Chapter Library C.IV.18; Paris, Bibliothèque Nationale lat. 6323; Florence, Biblioteca Laurenziana S. Croce $13 \sin .5$ and S. Croce $14 \sin .1$; Florence, Biblioteca Nazionale Conv. soppr. J.IV.22.

107 See C. H. Lohr, 'Medieval Latin Aristotle Commentaries. Authors A-F', Traditio 23 (1967) 356. I wish to thank Professor Lohr for notifying me of three additional manuscripts that did not appear on his original list, as well as for suggesting several useful bibliographic items. A tenth copy (namely, Admont, Stiftsbibliothek ms. 254) was sold about fifty years ago and its whereabouts is now unknown; cf. Aristoteles Latinus, Codices suppl., ed. L. Minio-Paluello (Bruges, 1961), p. 52, no. 29.

${ }_{108}$ For a complete description see R. A. B. Mynors, Catalogue of the Manuscripts of Balliol College Oxford (Oxford, 1963), p. 86. See also G. Lacombe, ed., Aristoteles Latinus. Codices 1 (Rome, 1939), p. 400, no. 343.

109 Described by Mynors, ibid., p. 89 and Lacombe, ibid., p. 401, no. 345.

110 See Lacombe, ibid., pp. 366-67, no. 273.

111 See F. Čáda. Codices manu scripti Bibliothecae Castelli Kynžvart in Bohemia Occidentali (Prague, 1965), pp. 122-30.

112 See Lacombe, Arist. Lat. Cod. 1, pp. 253-54, no. 34.

113 See ibid., pp. 544-45, no. 640 . 
$\mathrm{S}=$ Saint-Omer, Bibliothèque Municipale 595, fols. $165 \mathrm{v}-168 \mathrm{r} .{ }^{114}$ 13th century; in an uncultivated hand.

$\mathrm{V}=$ Vienna, Österreichische Nationalbibliothek 2302, fols. $127 \mathrm{r}-128 \mathrm{r} .{ }^{115}$ Beginning of the 14th century; carelessly written by a Belgian or Rhenish scribe.

$\mathrm{W}=$ Vienna, Österreichische Nationalbibliothek 5163, fols. 96v-99r. ${ }^{116} 14$ th century; in a cramped and careless hand, frequently corrected.

In preparing the first printed edition of Alfred's Tractatus in De plantis I made the decision to collate and include in the apparatus all of the above manuscripts, even though several, like $M$ and $W$, add very little to the establishment of the text. With the exception of the Kynžvart and the two Vienna codices, I examined all of the manuscripts in situ, having first taken the transcription/collation from microfilm copies.

There are two distinct families: DMPVW and BCKS. Within the former P and $\mathrm{V}$ are most closely related and are possibly copied from the same exemplar; $\mathrm{W}$ is perhaps a second or third cousin, though of genetically inferior stock. ${ }^{117} \mathrm{M}$ is a distant uncle with a goodly share of peculiarities. The most faithful witness is $\mathrm{D}$, although it does not appear to be the earliest. $\mathrm{D}$, moreover, has been corrected by a second hand in accordance with a better manuscript and also in the corrector's hand gives a number, of alternate readings; the latter, introduced by $u e l$, are not always improvements of the text.

The relationship among members of the BCKS family is more complex, and it is impossible to establish a close kinship between any two manuscripts; in this group $\mathrm{C}$ is the most distantly related and can almost be said to represent a distinct tradition. With some hesitation, therefore, I propose the following stemma: ${ }^{18}$

114 See ibid., p. 445 , no. 425.

115 See ibid., p. 286 , no. 105.

116 See Tabulae codicum manuscriptorum praeter graecos et orientales in Bibliotheca Palatina Vindobonensi asservatorum 4 (Vienna, 1870), p. 46, where it is not, however, properly identified.

117 Many of W's readings, in fact, can only be explained by postulating that its scribe was illiterate or drunk, or both.

118 I am most grateful to Dr. Fred Mis of Fairfield University's Computer Center for devising a computer-assisted grid analysis of the variants for me. 


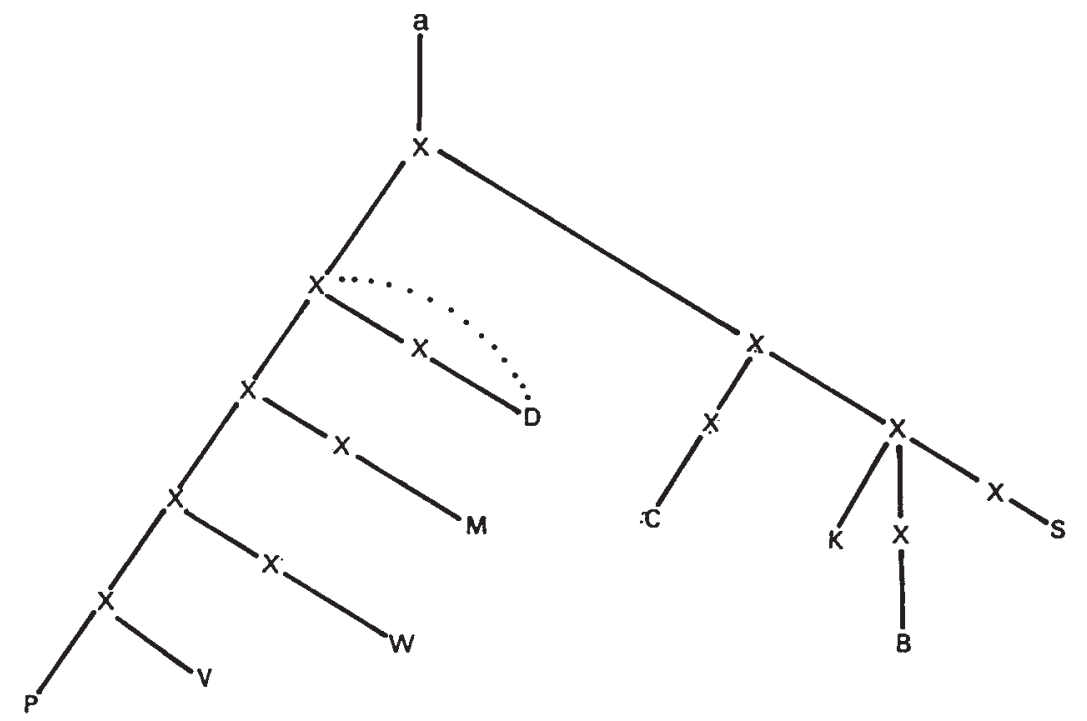

Only once did I find it necessary to emend the text. ${ }^{119}$ Since, moreover, I tended to prefer the readings of $\mathrm{D}$, at times against all or most of the other readings, I decided also to follow the orthography of $D$, even when inconsistent (e.g., subtilis/suptilis). The word order, unless otherwise indicated, is also that of D. I have not noted additions, omissions, or variant readings of conjunctions like enim, autem, uero, and etiam, except where the meaning was possibly affected; nor have I noted obvious scribal errors or purely orthographic variants. Punctuation, capitalization, and paragraph divisions follow the canons of modern English. Lemmata have been set off in upper case letters.

Because the lemmata are generally too brief to be intelligible without a context and because Meyer's edition is not readily accessible, ${ }^{120} \mathrm{I}$ thought it advisable to reproduce the relevant portions of the De plantis text below Alfred's commentary. This context also renders more understandable some of Alfred's more sketchy comments.

For the Meyer edition to be serviceable, however, it needed to be corrected. Of the approximately 170 extant manuscripts of the De plantis, Meyer utilized only three in establishing his text. ${ }^{121}$ Apparently unaware of the existence of

11 See Appendix A.

120 The National Union Catalogue (1968-72), for example, lists only seven American libraries that hold the book.

${ }^{121}$ De plantis (Meyer ed., pp. xxv-xxvi). For the Wolfenbüttel manuscripts, see Lacombe, Arist. Lat. Cod. 1.686-87, nos. 942 and 944, and for the Basel manuscript, ibid. 2 (Cambridge, 1955), pp. 813-14, no. 1148 . 
Alfred's commentary, moreover, he relied too hẻavily on Albert's. ${ }^{122} \mathrm{My}$ procedure was to collate an additional seven manuscripts, ${ }^{123}$ emending Meyer's text wherever both sensus and consensus dictated, without however indicating manuscript support. ${ }^{124}$

There are thus three apparatus, arranged in the following descending order: the apparatus criticus, the apparatus fontium, and the relevant passages from the reedited De plantis. Lines demarcate the apparatus.

I acknowledge with gratitude the support of the Penrose Fund of the American Philosophical Society, which enabled me personally to examine all but two of the manuscripts containing Alfred's commentary. I am grateful as well to Fairfield University for grants enabling me to study De plantis manuscripts in Rome and Florence and to purchase microfilms. Lastly, I wish to thank Yale University for a Visiting Faculty Fellowship, which afforded me the library resources to complete the research.

\section{INCIPIT TractatVs Alvredi \\ SUPER LibrVM de VegetabiLibVS}

VITA IN ANIMALIBVS ET PLANTIS INVENTA EST. Inferioris mundi corporum quatuor sunt prima genera: confusa, congelata, plante, animalia. Sunt autem

1-2 commentum super librum de uegetabilibus $B$ : Aluredus super librum de plantis $C$ : commentum Alfredi super librum de uegetabilibus $K$ : commentum Averroys super librum de plantis $M$ : commentum Alueredi super librum Aristotelis de uegetabilibus $P$ : incipit... uegetabilibus om. $S V W \quad 3$ inuenta est] et cetera $P V W$

3 'Vita in animalibus et plantis inventa est' (Meyer ed., p. 5).

122 Meyer, De plantis, pp. xxvi-xxvii; given Albert's inferior copy text we now know that such a reliance was unwarranted (see, e.g., Appendix B). Alfred's commentary, on the other hand, can occasionally determine the correct reading and should be a valuable aid in any future edition of De plantis.

${ }^{123}$ They are: Clermont-Ferrand, Bibliothèque de la Ville 168; Florence, Biblioteca Laurenziana S. Croce $13 \sin$. 5, S. Croce $14 \sin .1$, and S. Croce $15 \sin .1$; Florence, Biblioteca Nazionale Conv. soppr. J.IV.22; Paris, Bibliothèque Nationale lat. 6323; New Haven. Yale University, Beinecke Library Cushing 12. The choice of these particular manuscripts was dictated solely by convenience and accessibility, since I found myself in Florence when I made the decision thus to proceed; of the two remaining either I owned the copy or the original was nearby.

${ }^{124}$ This methodology, while scientifically unsatisfying, has the virtue of expedience, that is, the correcting of a flawed text while at the same time avoiding a cumbersome apparatus. The number of emendations, on the other hand, should indicate to the reader the desirability of a truly critical edition of De plantis. 
5 confusa que sola mixtione ab elementari extremitate distorta elementorum quam proxime seruant uestigia, ut que uulgus dicit elemența. Congelata uero sunt que generationem augmentumque tantum recipiunt. Crementum uero et sensum repudiant; sunt enim substancia corporea, inanimata, terminata. Planta uero, que radice suffulta, generationem suscipit et crementum; est enim

10 substancia animata insensibilis. Animal uero est substancia generationem crementum sensumque suscipiens; est enim substancia animata sensibilis.

Horum in duobus, scilicet planta et animali, dicit uitam esse inuentam. In hiis enim tria illa conueniunt que in libro De generatione et corruptione, capitulo de qualiter aliquid crescere dicatur, assignantur que non preter naturam sed supra

15 naturam. Nemo etiam notus esse ignorat. Animata enim sunt predicta corporea. Quid uero naturam disiungat ab anima ipse determinat in ANIMALIBvs. In animalibus enim multi anime apparent effectuș. Vnde et in ipso uita euidenter apparet. In planta uero pauci sunt anime effectus. Vnde et in ipsa est uita occulta. Vix enim dinoscitur in quo differat a congelatis.

20 AD HVIVs ENIM. Confusa enim occulto augmento et diminutione ei in tantum similia sunt, ut fere crescere uideantur.

5 mixtione ab] commixtione et $M$ elementari] elemento $W$ distortal discorsa $P V$ 6 proxime] proximo $C$ : proprie $P V \quad \operatorname{dicit}$ dixit $K$ : dici $P \quad$ elementi $K \quad 7$ augmentumque] augmentaret $C$ : alimentumque $P$ : alimenter $V$ recipiunt] suscipiunt $V \quad 8$ sunt enim] sicut est $M$ substancia] confusa $S$ inanimatal materiata $V$ terminata] creata $V: o m$. $W 9$ que] de add. $W$ suffulta $D W$ : fulta $B C K M P S V$ suscipit] -iunt $W$ : recipit $M \quad 10$ animata] anima $B$ insensibilis] sensibilis $K V W$ est om. $B C K M$ generatione $P 12$ dicit uitaml ostendit uita $P$ inuentam] in planta et animali $V \quad 13 \mathrm{de}^{2}$ ] diuide $P V:$ om. $M \quad 14$ qualiter] qualitate $B$ : quantum $W$ aliquid] -quod $P V$ assignantur] -atur $K:$-ant $P V W$ : -ans $D$ preter] propter (uel preter add. man. post.) $S$ naturam om. $W 15$ notus] motus $M$ : notum (corr. ex notus $V$ ) $V W$ corpora $M V W 16$ quid] quod $V W$ natura $V$ disiungat] distingat $M$ : distingwant $W$ determinant $W$ : in libro add. $M$ in animalibus om. $C W \quad 17$ multe $P W$ apparent] appetit $B K \quad$ ipsa $M V W$ : ipsis $C \quad 18$ pauce $B \quad$ est om. $B C \quad 19$ occultata $W$ dinoscitur] cognoscitur $C 20$ huius] hoc $M$ enim] et cetera add. $W$ occulta (uel -to add. in marg. $D$ ) $B D$ : oculo $P V$ augmento et diminutione] augmentum et diminutionem $V$ in tantum $D S W$ : iterum $C$ : om. $B K M P V \quad 21$ simili $P \quad$ fere] uere $M$

6 Cf. Adelard of Bath: 'Composita enim haec, quae sensu percipimus, non ipsa, sed ex ipsis sunt. Quare nec terra nec aqua nec aer nec ignis, ut philosophus ait [Tim. 49D], sed terreum, aquaticum, aereum, igneum dicenda sunt. Ex eo tamen, quod in singulis magis abundat, appellationem hanc sortita sunt' (Quaeștiones naturales, ed. M. Müller [BGP(T)M 31.2; Münster i. W., 1934], p. 6).

13 Aristotle, De generatione et corruptione 1.5 (321a18-29).

16 idem, Historia animalium 8.1 (588b4-589a3).

16 'in animalibus manifesta apparens, in plantis vero occulta, non evidens' (ibid.).

20 'Ad huius enim assertionem multam necesse est inquisitionem praecedere. Constaret enim utrum habeant nec ne plantae animam et virtutem desiderii dolorisque et delectationis discretivam' (ibid.). 
DESIDERIO MOVER, florum scilicet et frondium et fructuum; horum enim absentiam illis molestam esse dicebant.

QvORVM ANAXAGORAs. Huius enim erat opinio quod plante tum solaris 25 temporis tum florum et fructuum succique amissione uehementer tristabantur. Ad quod signum folia eicere dicebant.

SEXvM. Quicquid enim ab aliquo manente per generationem educitur, per tercii actionem fieri uidetur. Quid autem circa plantas de sexu dicendum in sequentibus determinabitur.

30 Plato. Ille enim uim attractiuam, retentiuam, digestiuam desiderium uocat. Sic enim se habentia desiderare uidentur. Aristoteles uero ipsam ueritatem in disputacione elimat et ideo sic infert:

QVIDAM AVTEM HABERE: in quibus uegetabilia a congelatis differant determinat. Vegetabilia enim nascuntur, crescunt, et secundum temporum habitudines 35 constituuntur, senectute quoque intereunt - que omnia cum animalibus plante

22 horum] si add. $P$ enim] si $V \quad 23$ absentia $V W$ molestiam $B$ dicebant] debeant $V$ 24 huius] horum $C$ erat om. $C$ tum $D S: \operatorname{cum} B K P W: \operatorname{tamen} C$ tum solaris] consolatis $V$ : consoleratur $M \quad 25$ tempore $M \quad \operatorname{tum} D K S:$ cum $P V W: \operatorname{tam} B C:$ om. $M$ succique $C D$ : siccique $K$ : succi $P V$ : sutuque $S$ : sutaque $B$ : suaque $M$ : sustinent $W \quad$ amissionem $W$ tristantur $M P V$; et stabantur $K \quad 26$ dicebat $W \quad 27$ aliquol agente $W$ : accidente $P V$ 28 per tercii] percii $K \quad 28$ tercii] $\operatorname{sexum} M$ : certam $W$ actionem om. $M$ super plantas $V$ : in planta $M \quad$ sexibus $M \quad 28-29$ in sequentibus determinabitur] propter ea determinationibus $V \quad 30$ digestiua $P$ desiderium] notat uel $a d d . D 31$ sicut $V$ enim] nec $P$ Aristoteles] harum $W \quad 32$ disputacione elimat] dispensatione eliminat $M \cdot$ infert] insunt $K W$ 33 quidam] quidem $K:$ quod $V$ a] et $P: o m . K$ differant]-unt $C M S$ determinat] -ant $B K S W$ : -auit $C \quad 34$ temporum] ipsum $B K$ habitudines] consueturdines $C S$

30 Plato, Timaeus 77A-C. Cf. Costa-ben-Luca: 'Opus vero vegetabilis animae est nutrire et reficere; hoc autem facit per quatuor virtutes, quae vocantur naturales, quae sunt: attractiva, retentiva, digestiva et expulsiva' (De differentia animae et spiritus 3, trans. John of Spain, ed. C. S. Barach [Innsbruck, 1878], p. 137).

22 'Anaxagoras autem et Abrucalis desiderio eas moveri (dicunt add. Meyer), sentire quoque, et tristari delectarique asserunt' (ibid.).

24 'Quorum Anaxagoras animalia esse has laetarique et tristari dixit, fluxum (flexum Meyer) foliorum argumentum assumens' (ibid.).

27 'Abrucalis [i.e., Empedocles; see Arberry, 'Notes ... I' (above, p. 131 n. 46), 220] autem sexum in his permixtum opinatus est' (ibid.).

30 'Plato siquidem desiderare tantum eas propter vehementem nutrimenti necessitatem ait. Quod si constet, gaudere quoque et tristari, sentireque eas, consequens erit. Id quoque constare desiderem an somno reficiantur excitenturque vigiliis, spiritum quoque et sexum per mixtionem sexuum habeant, vel contra. Multa autem circa haec ambiguitas longam facit inquisitionem (ibid., pp. 5-6).

33 Quidam autem habere animas has dixerunt, quia generari nutriri augeri, virescere juventute, senioque dissolvi conspexerunt, cum nullum inanimatum haec cum plantis habeat communia' (ibid., p. 6). 
sunt communia. Vnde quidam eas animalia esse dicebant propter consimiles uirtutes que eis insunt communiter. Congelata uero nullam istarum uirtutum habent. Quedam tamen eorum augentur nec crescunt; quedam uero eorum semper uno modo permanent, ut ipse in Metheoris et in libro De congelatis. In

40 huius etiam secundo causam huius assignat.

DESIDERIO QVOQVE AFFICk, quod non est necesse. Ipse enim in libro De anima differenciam ostendit inter tres species anime, uegetabilem scilicet, sensibilem, et animalem.

NISI CVM SENSV. Est enim fames nutrimenti appetitus ex attractione mem45 brorum sensibilis fitque in solo stomacho. Prius enim necesse est ut sentiat superius os stomachi attractionem a membris huiusque appetitus molestia tristatur, patiens quod superuenientis cibi nutrimento exhilaratur. Vtrumque ergo mediante sensu fit. Sentit enim animal inopiam, unde et exasperatur, huiusque inopie subleuacionem intelligit, unde et dolor remouetur. Cessante 50 enim causa cessat effectus, et hec occulta fide cognoscimus.

\footnotetext{
36 quedam corr. ex quidam $V$ animalia] substantias $W$ dicebat $M \quad 37$ uirtutes] -em $V$ : -em uirtutis $W$ sunt $W$ nuliam om. $C \quad 38$ quedam $^{1}$ ] quidam $P W$ corum] horum $S$ : illorum $D$ augentur] augmentatur $W$ quedam ${ }^{2}$ ] quidam $C W \quad 39$ semper] sunt que $W$ ut om. $B$ in ${ }^{2}$ om. $B C P S V \quad 40$ secundo causam huius om. $P$ huius om. $W 41$ desiderio] duo $V$ : bene $W$ quod] secundum $K$ necesse] nature $M \quad 42$ ostendit] ponit $P V$ species] sensus $M$ : potentias $W$ scilicet $o m$. $M P W$ sensibilem om. $P 43$ rationalem corr. ex animalem $S \quad 44$ cum sensul consensibilis $V$ appetitis $C \quad 45$ sensibilium $W$ fitque] sitque $P V$ prius] post $W \quad 46$ superius om. $M \quad$ os] ei $C$ : ut $P: o m$. $V W$ attractionem] attractiua $W \quad$ a] et $V: o m$. $W$ huiusque] huiusmodi quoque $M$ : huius sed $P$ : sed $V W$ molestium $V \quad 47$ superuenitis $B$ : super uehementis $P$ exhilaratur $D M$ : exhileratur $P$ : exíllaretur $S W$ : exhilerat $V$ : exhibeatur $B K$ : exhuberatur $C \quad 48$ medietate $V$ fit] sit $P V$ exasperatur] expiratur $S \quad 49$ huiusque] huius quoque $M$ : uim sed $P V$ : uni sed $W$ subleuacionem intelligit] subleuantur subleuacione intelligetur $W \quad 50$ et hec occulta] ut oculata sic $W$
}

39 It is likely that Alfred had no particular passage in mind but was referring in general to the contents of Meteor. 4, which deals with the qualities and properties of matter and with what we call chemical change.

39 Avicenna, De congelatione (Holmyard and Mandeville ed., pp. 45-55).

39-40 ibid.: 'Fiunt autem lapides duobis [sic] modis conglutinacione et congelacione. In quibusdam enim lapidibus dominans est terra, in aliis vero aqua. Aliquotiens desiccatur lutum fitque primum quod medium est inter lutum et lapidem et deinceps fit lapis' (p. 45).

41 A general reference to De anima 2.2-4 and 3.12-13

43 animalis is derived from anima, not animal; on the dual sense of animalis see Bäumker, De motu cordis, p. $53 \mathrm{n} .1$.

41 'Quae si habuerint plantae, desiderio quoque affici credebant' (ibid.).

44 'Dico ergo (dicit Plato Meyer): quicquid cibatur, desiderat (cibum add. Meyer) et delectatur saturitate, tristaturque, cum esurierit (esurit Meyer); et non accidunt hae dispositiones nisi cum sensu' (ibid.). 
Hvivs IGITVR mirabiLis, id est cum diceret eos desiderare et tristari, innuebat eos sentire. Huius ergo mirabilis erat sententia qui eas dixit sentire.

INTELLECTVM INTELLIGENTIAMQVE. Hec in proximo cassabuntur, ubi nec eas sensum habere docebitur.

55 Dico. ERGO. Vaporum tres prime sunt species, quarum prima sui leuitate in aerem prorsus extollitur, secunda sui grauitate infra terram comprimitur, tercia inter utrasque media nec infra prorsus comprimitur nec tota supra eleuatur, et hec sola anime susceptioni congrua inuenitur. Causa prima in subtilitate difflua spontaneam coagulationem non recipit, de qua sufficienter in Metheoris agitur.

60 Secunda superflua sui compactione diffusioni repugnat. Vnde utraque in genere suo distemperatissima. Sola autem intemperies animam expellit, quod tam ratione quam occulta fide sensum est. Tercia uero nec exuberanti compactione comprimitur nec nimia liquiditate dissoluitur. Vnde et temperiei uicina, animacioni non prorsus contradicit.

65 DeSIDERIVM NON EST NISI EX SENSv. Prius enim necesse est ut moueat sensus opinionem, a qua ad rationem, ducem intellectus, fiat ascensus. Oportet enim ut mediante sensu quedam presumat opinio que ipsa, uel que ex ipsis elicita sunt,

51 huius igitur mirabilis] huiusmodi cum $M$ eos] eas $M W$ tristari innuebat] tristare inueniebat $W \quad 52$ eos] eas $M W$ huius... sentire om. $M$ eas] eos $B$ dicit $P V W$ 53 intelligentia $W \quad$ ubi] nisi $B \quad 55$ dico ergol duo igitur $M$ uapor $B$ : uaporis $M$ leuitate] subtilitate $V \quad 56$ grauitatem $P V$ comprimit $V$ tercia] estadd. $S \quad 57$ inter] in $M$ media] mediatur $C$ : est add. $W$ comprimitur] inprimitur $W$ totum $B K \quad 58$ hoc $P V$ susceptionem $P V$ congruam (corr. ex contraria $D) B D$ : communia $P V:$ om. $W$ causal cum $M$ : est $W \quad$ difflua] difusam $W \quad 59$ recipit] suscipit $P V \quad 60$ sui] sua $M$ compactione] comparatione $C M$ repugnat] -ant $C$ genere (corr. ex generatione) $D$ : generatione $M V W$ : gilatione sic $P \quad 61$ suol sua $M P V W$ sola] communia (?) $W$ : om. $P V$ autem] aristoteles $P V$ : et $W$ intemperiei $B C K S$ : intemperiens (?) $W$ expellit] expressit (add. in marg. uel pellit) $S$ tam] tamen $S \quad 62$ ratione] probatione $W \quad$ oculata $W \quad$ exuberanti] -antur $W \quad 63$ nec] ut $B C K$ temperiei (corr. ex intemperiei $D) D K M S$ : temperei $B C$ : intemperie (corr. ex temperie $V) P V$ : intemperet $W$ uicina] dissoluitur $P V W$ : in qua $S$ animacioni] anima communi $W$ 64 prorsus] corr. ex prius $D 65$ non] uero $M$ necessarium $M \quad 66$ a qua] corr. ex aliquam $D$ ducem] ducere $B C P S V$ intellectus] et $a d d . P V$ : cum $a d d . W$ assensus $C M$ : offensus $K$ : sensus $S$ : accessus $W \quad 67$ mediantel mediām (?) $B$ quedam] quod dicit $V$ ipsal quando $W$ que] exque sic $B$ : om. CMPSVW ipsis elicital illis eliciatur $W$ surit om. $P V$

52 i.e., Plato (Tim. 77B-c).

59 Arist., Meteor. 1.3-4 (340b22-342a35) and $2.4(359 \mathrm{~b} 27-361 \mathrm{~b} 13)$.

65 See idem, De an. $2.3(414 \mathrm{~b} 2-5)$.

51 'Hujus igitur mirabilis erat intentio, qui eas sentire et desiderare opinabatur' (ibid.).

53 'Anaxagoras autem et Democritus et Abrucalis illas intellectum intelligentiamque habere dicebant. Nos vero, haec ut foeda repudiantes, sano insistamus sermoni' (ibid.).

55 'Dico ergo, quod plantae nec sensum habent nec desiderium' (ibid.).

65 'Desiderium enim non est nisi ex sensu, et nostrae voluntatis finis ad sensum convertitur' (ibid.). 
anima desiderat uel appetit. Et hoc est ut ipse dicit in Analeticis posterioribus: Oportet quedam prius cognoscere, id est sensu comprehendere, deinceps ex

70 hiis scientiam aut desiderium aut similia colligere. Precedit ergo sensus desiderium.

Huic tamen obuiat quod et animam post abscessum a corpore quidam dicunt quedam desiderare. Quod et ipse in libro De anima determinat. Huius tamen molestie inoportunitas excluditur cum addidit NOSTRE, scilicet animalis. Scitum

75 enim est hoc in quolibet animali contingere.

Plantas omnes constat esse ex sensu precedenti, sicut ipse docet in Posterioribus analeticis esse in eis sensum, sensum scilicet qui toti corpori est communis, id est tactum. NEC MEMBRVM SENTIENS, id est nec membrum particulari sensui deputatum, ut aurem, oculum, et similia. Est ergo perceptio

80 inpressionis in instrumentum ab applicatione exteriorum. Prius enim oportet, ut instrumentum exteriorum applicatione aliquo modo inficiatur, quam affectionem percipiens anima sentit. Omnis ergo planta, ut plurimum, solide substancie est, unde et infert inpressionem facilius quam suscipit. In animali quoque nerui instrumenta sunt sentiendi: molles inpressioni cedunt, unde et in

85 hiis, hiis mediantibus, fit sensus; duri resistunt, unde et motus dicuntur, non sensibiles. Planta uero secundum plurimum hiis etiam est durior.

\footnotetext{
68 et hoc om. BCKS 69 oportet] sed $M V W$ : om. BCKS id est] in $P$ : et $V \quad$ deinde $M$ ex om. $M \quad 70$ similia] uniuersalia $K:$ alia $M:$ simul $W$ colligere] cognoscere $M \quad 72$ huic] hoc $B C$ tamen] enim $C$ : cum $P$ : non $W$ anima $B C K M S$ abscessum] accessum $B$ : ascensum $P V \quad 74$ moleste $P V \quad$ importunitas $C M \quad$ addit $M S$ : addiderit $P$ : accidit $K$ scilicet] que $C$ scilicet animalis] secundum aristotelem $W \quad 76$ plantas omnes] planta omnis $C \quad$ ex] a $M$ precedenti D: -te CMPSVW: pretente $B$ : preeunte $K$ dicet (add. in marg. docet) $D \quad 77$ posterioribus] prioribus $M$ esse om. $B C K P S V W$ eis] eas $V$ sensumª ${ }^{2}$ sensus $S$ : om. $K M P V W \quad$ scilicet] enim $S: o m . M \quad 78$ id est] in $B$ : scilicet $C \quad$ nec ${ }^{2}$ ne $P$ membrum] in add. $P \quad 79$ oculus $V$ preceptio $S \quad 80$ in om. $B C K M P S V$ instrumento $W$ extraniorum $M$ : extrinsicorum $W$ prius om. $P \quad 81$ instrumentum exteriorum] instrumenta exteriori $W$ aliquo] alio $C$ modo om. $M$ inficiatur] -ant $S$ quam] per $a d d . B$ 82 affectionem] affectum $W \quad 83$ fert $P$ impressionem] passionem $M$ suscipit] recipit $M$ animalibus $S \quad 84$ sunt om. $M \quad$ sentiendi] conciendi $K$ in del. $S \quad 85$ hiis $^{2}$ om. $B C K M S W$ dure $W$ motus] uel moti add. $D$ 85-86 non sensibiles] insensibiles $C$ 86 hiis] habens $M$ est om. $B C K S$
}

68 idem, An. post. 2.19 (100a3-b4).

73 There is no such discussion in Aristotle's De anima. Avicenna explicitly denies any sensible power, including desire, in the separated soul (Liber de anima seu Sextus de naturalibus 4.4, ed. S. Van Riet [Louvain, 1968], pp. 66-67).

77 Alfred must have had in minḑ De anima 3.13 (434b9-24). Cf. De motu cordis 10 (Bäumker ed., p. 43), where he correctly cites the De anima. There is no such discussion in the Posterior Analytics.

80 Cf. Arist., De an. 2.12 (424a33-b3). 
Item nichil fit cuius ortum legitima causa et ratio non precedat. Sensus uero ad hoc datus est, ut cognoscentes quorumdam nobis applicemus presentiam ob manifestas inter alias utilitates, quarum nullam plantas posse adipisci occulta 90 fide compertum habemus. In hiis ergo superflueret sensus. Relinquitur ergo ut nec eis sensum natura reliquerit nec Creator inesse sustinuerit.

NEC FORMAM CERTAM, scilicet quantitatis et qualitatis et numeri partium mensuram. Vel igitur sentiendi potestas in planta producitur in infinitum, et ita illa perfectior erit animali, uel, si citra partes determinatas potestas sentiendi 95 extenditur, quedam partes plante insensibiles relinquuntur, que omnes inter se similitudines inueniuntur. In animali siquidem cum membrum superfluum, ut digitum aut simile aliquid, natura producit inutile et inhabile, et fore nature regimine destitutum inuenitur.

NeC SIGNYM ALIQvod. Membra enim singularibus sensibus deputata ab aliis in 100 aliis sibi similia sunt, ut oculi irradiacio, naris concauitas, et similia.

NEC CONSTAT HOC, quod planta sit animata, nisi propter has uirtutes quas eam constat habere ab anima.

CAvSA eSt Illvstrationis. Vita enim sine sensu mortis tenet ymaginem; sensus uero uitam fere ducit ad actum.

87 item] cum add. $V$ fit] sit $V$ cuius] eius $C$ causa om. $C$ ratio] prima $W$ 88 quibusdam $P V$ ob] ad $W \quad 89$ manifestas om. $B S$ alias] illas $W$ posse] personale $C$ : 88 adipisci] adypoyti sic $V \quad 90$ compertum] apertum $P V$ superflueret] -uit (uel superflueret in marg. D) $D W$ relinquitur] sequitur $V$ 91 sensuum $B$ reliquit $W$ :-quunt $B S$ sustinuerit] firmauerit $M \quad 92$ certam] incertam $K \quad$ scilicet] secundum $M$ et qualitatis om. $W$ partium om. $W \quad 93$ mensuram] -ur $P$ uel] animal $B$ : nihil $K$ plantis $M \quad 93-94$ ita illa] citra illam $W \quad 94$ erit] est $M \quad$ si om. $B$ deterioratas $P$ potestas] positas $B \quad 95$ quidam $P$ relinquuntur que] "relinquitur quod $W \quad 95-96$ inter se similitudines] inter similes $W \quad 96$ siquidem] si quid $C K$ : si quod $P V W$ : susceptibilis $M$ cum] tamen $P V$ : tantum $W \quad 97$ digitum autl digestum et $K$ simile aliquid] aliquid tale $M$ : substantie aliquod $W$ inutilem $W$ inhabilem $W$ : inhabile et $o m$. $P$ forel forte $M$ : forme $P$ : informe $C$ nature] nec $M \quad 98$ regimine] regine $B$ : regimini $M$ : regimen $W$ destitutum] definitum $M \quad 99$ membra eniml membrana $P$ : natura $W \quad 99$ singulis $V$ deputata $0 m . C$ aliis] alio $B K S$ : aliquo $C \quad 99-100$ in aliis] malis $P \quad 100$ similia'] similes $V$ sunt $o m$. $W$ irradiacio] radiacio $M: o m$. $W$ naris concauitas] concaui talis $W \quad 101$ constant $B$ eam] $\begin{array}{lll}\text { causa } P & 102 \text { constat] uidemus } M \text { habere om. } P & 103 \text { est om. } P V W \text { illustrationem } B\end{array}$ sine] bis $V$ mortis] motis $B \quad 104$ uero] enim $D \quad$ uitam] necessario $M$

92, 99 'Nec invenimus in eis sensum, nec membrum sentiens, nec similitudinem ejus, nec formam terminatam, nec consecutionem rerum, nec motum, nec iter (viam Meyer) ad aliquod (aliquid Meyer) sensatum, nec signum aliquod (om. Meyer) per quod judicemus, illas sensum habere, sicut signa, per quae scimus eas nutriri et crescere' (ibid., pp. 6-7).

101 Nec constat hoc nobis, nisi quia nutrimentum et augmentum partes sunt animae. Cumque plantam talem invenimus, aliquam partem animae illi inesse necessario intelligamus (-gimus Meyer)' (ibid., p. 7).

103 'Sensuque careat tunc (carentem Meyer) esse concedere (contendere Meyer) non oportet, quia sensus est causa illustrationis vitae, nutrimentum vero causa est augmenti rei vivae' (ibid.). 
105 Vite animalis. Vita enim in eo quod uita una ex causa et uno regimine suis debet inesse subiectis.

Qvia SVNT QVEDam animalia. Bene dico quod, quia non sentiunt, non uiuunt: quia sunt quedam animalia que dignioribus uirtutibus illis carent, quibus uideretur uita animali inesse. Et tamen hec per generationem prolem faciunt,

110 quod est ex sensu. Non enim appeteret animal coitum, nisi eo delectaretur. Plante uero sola propagacione prolem faciunt, quod non est ex sensu. Cum ergo animatum et inanimatum inmediata sint, et planta inanimata esse non possit, dicenda est animata non uiuens.

SCIMvs AVTEM Qvod CONChILiA. Hec sunt que hanc generalitatem uidentur

115 excludere, que est: nullam plantam sensum habere. Posset enim obici sensum in plantis superfluere, cum discretionem non habeant nec commoditate sensus possint uti.

Respondeo quedam animalia esse que eodem modo se habent, id est nullo genere discretionis utuntur, que tamen, ut plante, generantur et corrumpuntur.

120 In eis ergo eque sensus superflueret.

\footnotetext{
105 in] ex $M \quad$ ex om. $M \quad$ causa] una $a d d . W$ regimine] regione $P$ 105-106 suis debet] signet $K \quad 106$ subiectis] substantiis $B M V W$ : que add. $C \quad 107$ quia'] uiua $P V$ quedam om. $W$ bene] unde $P V$ quod $o m . B C$ uiuunt] insunt $M \quad 108$ sunt] secundum $C$ quedam om. $K$ illis] animalis $M:$ om. $W \quad 109$ uidetur $M W$ : uidentur $B$ animalis $M W$ tamen] cum $M P V$ : animalia $W \quad 110$ quod] que $S$ animal] totum $a d d . B$ animal coitum] ex coitu $M$ eo om. $M W$ eo delectaretur] condelectaretur $V:$ in eo add. $W$ delectaretur] desiccarentur $B \quad 111$ plante $D$ : planta $B C K M P S V W$ faciunt $D$ : facit $B C K M P S V W$ quod non est ex sensu om. BCKMPSVW ergo] enim uel ergo $D$ 112 inmediata] mediata $M$ : immeata sic $P$ sint] sunt $P$ inanimata (corr. ex animata $D) D M$ : animata $C K P S V W$ : anima $B \quad$ non] uero $P$ : om. $K \quad 113$ dicenda] dicta $V$ : dauda sic $W$ anima $W$ non] nisi $B \quad 114$ scimus] cuius $P V$ : widemus sic $W$ conchilial consilia $S$ hec om. $P V$ hanc] habeat $B:$ om. PVW generaliter $V 115$ est om. $W$ plantam om. $P$ habere] nostre $K$ : posse $a d d . M$ enim] hic $a d d . M$ obici] subici $M 116$ discretionem] desiderium $M$ habeant] -ent $V:$ om. $P \quad 117$ possint $M$ : -ent $D P$ : -unt $C K S W$ : potest $B: o m$. $V$ 118 respondemus $W$ esse om. $P V$ id est om. $M$ nullol modo add. $V \quad 119$ que] quo $K$ tamen] est $a d d . V$ ut] in $B$ generatur $P$ et corrumpuntur] incorrumpuntur $P$ 120 eis] hiis $M V \quad$ eque] que $P V$ superfluent $S$ : superfueret sic $V$
}

105 'Dicet quoque aliquis plantam, si sit vivens esse, animal. Namque difficile est vitae plantis (plantarum Meyer) regimen assignare praeter regimen vitae animalis (altricis Meyer)' (ibid.),

107 'Quod (qui Meyer) autem plantas vivere negant, est quod non sentiunt: quia (quamquam Meyer) sunt quaedam animalia sapientia et intellectu carentia. Natura tamen, animalis vitam in morte corrumpens, ipsam in genere suo per generationem $(\mathrm{om}$. Meyer) conservat; estque inconveniens, ut inter animatum et inanimatum medium ponamus' (ibid.).

114 Sç̧mus autem quod conchylia animalia sunt sapientia et intellectu carentia, suntque plantae et animalia' (ibid.)., 
Item quedam animalia et plante sunt, ut ostrea et omnia conchilia. Conchis enim suis radicitus affixa sunt et senciunt. Plante ergo senciunt.

Soluit dicens quod 'solus sensus causa est quare dicantur animalia.' Senciunt ergo non in eo quod plante.

125 Priorem obiectionem soluit in libro De anima, dicens conchilia cum senciunt qualitercumque discernere; unde ad libitum conchas aperiunt uel claudunt. De serpentibus, qui radicitus terre affixi sunt, hic tacuit. Manifeste enim habent motum uoluntarium et membra singularibus sensibus deputata.

Qvia GENERA DANT. Ac si diceret: dicitur animal, quia est substantia animata

130 sensibilis.

QVIA GENERA, et cetera, id est ex genere est diffinitio et nomen diffinitioni. Equale est enim diffinitio et ratio nominis, idem significans, ut hec substantia animata sensibilis et hec appellatio 'animal'. Species uero suis indiuiduis dat nominationem, quod de specialissima intelligendum est.

121 item] id est $W$ et $t^{1}$ ut $V$ suntom. $P V W$ ut] et $W$ ostrea om. $P$ omnia om. $V$ conchilia] consimilia $B \quad 122$ radicibus $K$ : raditus $W$ obfixa $C$ 'sunt om. $W$ senciunt $\left.{ }^{1}\right]$ certi et $P$ : terre $V: \dagger \ldots \dagger W \quad$ ergo] non $a d d . B \quad$ senciunt $\left.{ }^{2}\right]$ quod solus est dominus add. $W \quad 123$ dicens om. $W$ solus om. $P$ causa om. $C M$ dicantur] -unt $M$ 125 priorem obiectionem] prioris officium solus autem $W$ obiectionem] effectum $P V$ dicens om. $K \quad 126$ qualitercumque] qualiter oportet $P$ aperuit $W \quad 127$ radici $W$ affixe $M W$ : confixi $V$ manifeste] maxime $B \quad 128$ motum] ut modicum $M$ uoluntarium] et motum add. $B$ singulis $V W \quad 129$ dat $V$ quia'] quod 'BCKPSV: animal add. $M$ 130 sensibilis] et hec appellatio animalis $a d d . M \quad 131$ et cetera om. $P V W$ id est ex] rex $P$ est $^{2}$ om. $B \quad$ nomen] natura $B:$ non $P V W$ diffinitioni] diffinitio $W \quad 132$ equare $S$ : inequale $W$ et $o m . B C S$ rationis $W$ nominis] nomine $K:$ om. $W \quad 133$ animatal anima $P$ animall anima et $W$ uerol in add. $K$ dat om. $B C K S \quad 134$ quod] quia $C$ specialissimis $P V$ : speciebus $W$

125 There is no mention of shellfish in Aristotle's De anima. Alfred is doubtless referring to the text in Avicenna's De anima (or Liber sextus) 2.3: 'Divulgatum est quod animalium quoddam est habens sensum tangendi et non habet virtutem movendi, sicut species conchylium. Dicemus ergo quod motus voluntarius duplex est: quia et est motus localis de loco ad locum et est motus contrahendi et extendendi membra animalis ex quo non provenit motus totius de loco suo. Impossibile est autem ut animal habeat sensum tangendi et non habeat in se virtutem motús aliquo modo: quomodo enim sciretur habere sensum tangendi, nisi videretur in eo aliquis modus refugiendi contactum unum et appetendi alium? Unde exemplum de conchylibus quod inducunt et de aliis nihil valet, quoniam nos videmus conchylium in suis corrchis motus constrictionis et dilatationis et reflexionis et extensionis in partibus earum, quamvis non discedant a loco suo,"et ex hoc cognoscimus quod sentiunt tactum' (ed. S. Van Riet [Louvain, 1972], pp. 132-33). Cf. Arist., Hist. an. 8.1 (588b12-23).

129 'Solus ergo sensus est causa, quare illa dicantur (dicuntur Meyer) animalia, quia genera dant suis speciebus nomina et definitiones, species vero suis individuis nomina. debetque genus ex una causa esse in multis, et non ex multis; intentio 'autem causae, per quam conformatur genus, non cuilibet est pervia' (ibid.). 
135 SVNT AVTEM ANIMALIA QVE SEXv CARENT, et cetera, quasi dicat: hee proprietates genus adesse non ducunt, cum omnibus communes non sint.

NON HABET AVTEM PLANTA MOTVM, quasi dicat nec motum, qui dicitur uitam constituere, scilicet uoluntarium, habet planta; superflueret enim in ea quia terre alligata est.

140 VITE COMmVNe EST SENSvs, quem, quia non habet planta, non uiuit.

QVia SENSVS FACIT, et cetera, id est per sensum scitur an uiuat animal.

ET HEC EST INVENTIO VITE. Hec enim substantialis et componens specifica. Ceterum eius priuatio non apponitur ut specifica, quia comitatur omne animal celeste ad nutum sui creatoris elementatum, ex nature scilicet defectu, sicut

145 aliqua 'bipedem' esse hominis proprium et 'mortale' partem diffinitionis species ponit, licet improprie.

135 sunt] si $M \quad$ animalia] animata $C \quad$ sexu (corr. ex. sensu $D$ ) carent] sensu carent $M$ : sexu causa $K$ : sexuta sit $C$ : secuta $P V$ carent] fit add. $B K S$ : et fit add. $D$ et cetera om. $P V W$ quasi dicat] quia diceret $C M$ hec $C V$ proprietatem $V \quad 136$ genus] generis $W$ : sunt $K$ ducunt] dicunt $V$ : inducunt $W$ communes] perfecte $M$ sunt $B C K M \quad 137$ habet $o m . V$ autem] quod $C:$ om. $W$ motum ${ }^{1}$ ] et cetera add. $M: o m . W$ dicat] diceret $C$ qui] quia $V$ uitam del. $W \quad 138$ scilicet] nec sensum $M: \operatorname{sed} P V W \quad$ plantam $B \quad$ superflueret] superfluum est $D$ : superfluumque $M$ enim om. $M$ quial quare $W \quad 139$ terre] terra $B: o m$. $W$ 140 non $o m . M$ planta non] sensum $W \quad 141$ quia $o m . W$ et cetera om. $M P V W$ id est] quia $B$ scitur] sentit $M$ an] quod $V \quad 142$ intentio $K M S$ uite] necesse $B$ enim] est $V$ componens] est add. $M \quad 143$ ceterum om. $W$ priuatio] specificatio $P V$ : prius $W$ specifica] sed $a d d$. $C K S$ : sperica $\operatorname{sed} B$ : specificatur $W$ comitatur] communicatur $C M$ omne om. $V 144$ nutum] mutum $C$ creatoris] conditoris $M$ elementatum] excreatum $M$ natura $B$ defectu] et defectus $B \quad$ sicut] si sit $W: \operatorname{sit} P V: \operatorname{scilicet} B \quad 145$ aliquam $V$ bipede $W \quad$ species] speciem $W$ : sensum $M \quad 146$ ponit] posita $P V$

144 See Chalcidius: '... ait deum post generationem stellarum ratarum, cum unaquaeque earum diuinum animal esset utens corpore mixto ex sincerissimis materiis quattuor et ex maiore parte ignis sereni' (Timaeus a Calcidio translatus commentarioque instructus 119, ed. J. H. Waszink, 2nd edition [Plato Latinus 4; London, 1975], p. 165).

135 'Sunt autem animalia, quae sexu carent femineo, et sunt quae non generant, suntque quae motum non habent, et sunt quaedam diversorum colorum, et sunt quae faciunt prolem sibi dissimilem, et. sunt quae ex arboribus crescunt' (ibid., pp. 7-8).

137 'Non autem habet planta motum ex se, terrae enim affixa est, haec autem immobilis' (ibid., p. 8).

140, 141 'Dicimus ergo, quod vitae animalis commune est sensus, quia sensus facit discretionem inter vitam et mortem; sed coelum, quia habet (cum habeat Meyer) regimen nobilius et dignius nostro regimine, elongatum est ab his' (ibid.).

142 'Oportet autem, ut animal perfectum et diminutum habeat (-ant Meyer) aliquid commune, et hoc est inventio vitae et ejus privatio. Nec oportet, ut quisquam recedat ab his nominibus, quia non est medium inter animatum et inanimatum, nec inter vitam et ejus privationem; sed inter inanimatum et vitam est medium, quia inanimatum est, quod non habet animam nec aliquam partem ipsius. Sed planta non est de his, quae carent anima, quia in illa est aliqua pars animae; et non est animal, quia in illa non est sensus; et exit de vita ad non vitam (mortem Meyer) paulatim ut singula. Possumus etiam alio modo dicere, quod est animatum. Et non dico tamen quod sit inanimatum, si habuerit animam et aliquem sensum (quod est add. Meyer), quia res, quae cibatur, non est sine anima, et omne animal habet animam' (ibid., pp. 8-9). 
Nota quod anima uegetabilis in officio sibi deputato est infinita et interminata circa suum proprium subiectum, quia numquam in aliqua arbore tot ramos uegetat quin plures in eadem possit uegetare. Similiter anima animalis in sensu 150 et ymaginatione se habet; similiter etiam anima rationalis se habet in ratione et intellectu, quia numquam tot intellectu comprehendit quin plura possit compre hendere.

QVOD AVTEM COMEstiBile. Nota quod planta quandoque nascitur proprie, quandoque per accidens. Proprie, quando planta calide nature in loco calido, 155 temperata planta in loco temperato, frigida in loco frigido - et hoc ex natura terre producentis materiam plante, scilicet humorem et uaporem, sibi similem in natura. Per accidens nascitur planta, calida in terra frigida, quia ex frigiditate constringuntur pori eius superficiei et includitur aer, quo calefacto aere exteriori mouetur uehementer. Et uehementer suscipit calorem, cum non possit

160 exalare, et humorem et uaporem attrahit, quo uapore augmentato et multum calefacto tandem prorumpit in plantam calefactam; sibi enim simile producit.

E contrario in loco calido nascitur planta frigida, quia ex caliditate aperti sunt pori, et uapor calidus et subtilis euaporat; qui autem frigidus est et grossus, scilicet terre et aque uicinus, adunatur et procedit in plantam. Vnde frequentius 165 in calida regione prouenit planta frigida quam in regione frigida, et e contrario.

147 sibi] sit $K \quad$ deputata $B$ indeterminata $M W \quad 148$ aliqual alia $B C$ : om. $M$ rami (corr. ex ramos) $S \quad 149$ uegetat] -ant $B S$ plueres sic $W$ in eadem om. $M$ possit] -et $M$ : -int $V$ similiter] quare $P$ : quam $V$ : cui $W$ sensul sexu $W \quad 150$.et $\left.{ }^{1}\right]$ in add. $B C K P$ ymagine $P W \quad$ similiter] sicut $C$ in om. $S$ 150-151 ratione et intellectul rationem et intellectum $W \quad 150 \mathrm{et}^{2} \mathrm{om} . C \quad 151$ nuncquam $C$ intellectus $S W$ possit] -int $C$ 153 quod $^{1}$ quoniam $M$ quod ${ }^{2}$ om. $W$ proprie] per se $M \quad 154$ quandoque ... proprie om. $C$ per om. $P$ quando] quandoque $B$ plantal plante $B:$ proprie $a d d . M: \operatorname{tarde} a d d . W$ calide] tarde $P$ nature] est add. $M: o m$. $W \quad 155$ planta om. $W$ loco om. $M$ hec $M$ ex natura] est nota $V 156$ producentis] productionis $P V$ materiam] -ia $P V$ : naturam $M$ sibi] igitur $C \quad$ sibi similem om. $W \quad 157$ in natural innota $V \quad 157-158$ frigida ... et om. $K$ 157 frigiditate] siccitate $M \quad 158$ eius om. $M W$ quo] in eo $W \quad 159$ exteriora $B$ : exteriore $S$ uehementer'] uehementem $D$ et uehementer om. $P V$ uehementer ${ }^{2}$ ] uehementem $B K S$ 160 exalare] sere $P$ uapore augmentato] attracto $M \quad 161$ tandem prorumpit] eandem prorumpat $W$ calefactam] calidam $B C K S$ sibi enim] simile $M$ enim] sibi add. $W$ producit] -xit $V$ : et $a d d$. $W \quad 162$ locol loquo sic $K$ caliditate] calefacto $D \quad 163$ et subtilis om. $W$ et grossus] egressus $V$ grossus] sic add. $W \quad 164$ uicinius $P V \quad$ et $^{2}$ om. $W$ unde] et non $C \quad 165$ regione] corr. ex religione $B$

153, 174-175 Quod autem comestibile est ex planta, erit in locis calidis lenibus altis, et maxime in climate tertio et quarto; et quod erit prope cibum, in locis frigidis et altis. Et ideo multiplicantur species in locis' frigidis altis propter attractionem humorum et temperantiam in calore solis in diebus vernalibus' (ibid., p. 35). 
Similiter in loco temperato secundum diuersas aeris consistentias per accidens producitur planta quandoque calida, quandoque frigida. Cum uero planta aliqua, in quocumque loco fuerit generata, tantum simile attrahit ad suum nutrimentum, dissimile autem ut abhorribile repellit - et hoc naturali 170 electione, appetitu, et desiderio.

COMESTIBILE. Nichil est comestibile nisi ex caliditate et humiditate sit perfecte digestum - et hoc ex materia subtili et digestibili, et nisi sit digestum calore extrinseco uiolente.

IN LOCIS CALIDIS. Hic loquitur de generatione plante propria et naturali.

175 LeNibvs ET ALTIS, quia in planis locis 'equaliter habundat humiditas. Et hoc si assit loci dulcedo et aeris temperies, similiter et in altis, quia ibi est aeris temperies et humiditas dulcis propter spongiositatem uaporem dulcem attrahentem. Et ideo frequenter in montibus maior est fertilitas et melior. In ualle enim difficile mouetur aer, unde ex conculcatione cito ibi

180 putrescit aer et uapor grossus. V.nde praua digestio, hinc etram est ibi humor salsus.

Plantam vnCtvosam Prodvcit. Ad hoc enim ut durabilis sit planta, oportet ut bene digestum et unctuosum habeat humorem. Vnde ille plante que habent humorem aquosum, liquidum, indigestum, superueniente frigiditate cito

185 arefiunt. Hac causa caulis ultra triennium non durat. Tamen si ei inseratur insita, ex natura insite multa in stipite fiet decoctio; et ita conuertetur in naturam insite, et ideo durabit diu.

166 aeris] existencias add. $C$ : om. $W \quad$ consistencia $K \quad 167$ plantal plantas $W$ : om. $M$ quandoquel] quando $M \quad 168$ aliqua] alia $W$ quocumque locol loco quodam $V$ generata] seruata $P V \quad 169$ sumb sui $B C K P S W:$ om. $V$ dissimile] difficile $K$ autem] aut $W$ : uero $C M: o m$. $V$ ut om. $W$ abhominabile $M$ : abortibilem $V$ : animal horribile $S$ : aberret et $W$ 170 electione om. $M \quad 171$ est] enim $W$ sit perfecte] perfectum et $M$ 172] digestum ... sit . om. $V$ material natura $W$ sit] fuerit $M \quad 173$ uiolente $D P W$ : uiolento $B C K S$ : uero littere $M$ : mouente $V \quad 174$ loco $V$ calidis] lenibus et altis add. $W$ loquitur] sequitur $P V$ 175 lenibus et altis om. $W$ altis] aliis $P V$ planis] plantis $B K$ equaliter] essentialiter $P V$ habundat] dulcedinis add. $M \quad 176$ hoc si assit] hoc asistit $W:$ hec resistit $M$ aeris] aeri $B$ intemperies $M \quad 176-177$ similiter ... temperies om. $V \quad 178$ attrahentem] eleuantem $M$ fertilitas] felicitas $B$ : frigiditas $M \quad 179^{\circ}$ melior] minor $M$ unde] et $a d d . M W$ ex] est $V$ cito om. $M \quad 180$ aer om. $P V$ praual parua $P V W$ hinc etiam est] huic et $B$. ibi om. $P$ 181 salsus] falsus $V \quad 182$ unctuosa $B V$ producit om. $P V W$ durabilis] durabis sic $W$ 183 iste $W$ habent] hunc $P \quad 184$ aquosum] siue $a d d . V$ frigiditate] superioritate $W$ 185 arefiunt] referunt $W$ hac] de add. $K$ triennium] terminum $M$ tamen si] nisi $V$ inseratur] insecatur $B C$ : inferatur $P S \quad 186$ ex natural per naturam $M$ insite] inserite $M$ in stipite] insipiente $W$ fiet] fit $W$ decoctio] decoctam $B$ conuertetur] -itur $V$ : corrumpetur $M \quad 187$ ideo] non $M: o m$. $W$

182 'Similiterque lutum ingenuum cito producit plantam unctuosam; et comprehensio ejus humoris (om. Meyer) est in aqua dulci, ut praediximus. Planta autem, quae super solidos lapides nascitur, longo tempore contingit' (ibid., pp. 35-36). 
ET PLANTA QVANDO DOMINABITVR. Ex temperie seruatur plante crementum. Ex nimia uero humiditate opilåntur pori, per quos nutrimentum debet ascendere, 190 quod tam in planta quam in animali in specie fumi et uaporis ascendit, ut ipse predixit in tercio capitulo secundi libri, et ita nutrimentum cogitur descendere et non nutritur planta. Simile contingit ubi nimia habundat siccitas. Ex siccitate enim constringuntur pori, ne nutrimentum possit ascendere.

TOTA SIQVIDEM PLANTA. Quelibet planta quatuor indiget.

SEmine terminato, id est in sua specie perfecto et maturo et absque putrefactioné conseruato.

LOCO CONVENIENTI, id est territorio. Et' hec duo necessaria sunt ad plante generationem.

AQVA MODERATA, id est humore temperato et plante conseruatiuo.

AERE CONSIMILI, id est temperato, quia si nimis sit calidus, euaporabit calor naturalis poris apertis. Si aer sit nimis frigidus, suffocabit plantam. Et hec duo sunt necessaria ad plante nutrimentum.

LOCO A SOLE REMOTA. Quanto aliquis locus est remotior a sole, tanto est ibi dies longior in estate. Vnde existentibus sub septentrione diem habent continue per

188 quando] quandoque $D$ dominatur $K$ seruatur] -antur $V$ : -abitur $C$ : generatur $K W$ ex om. $K \quad$ temperie $B D P$ : tempore $C K M S V W$ 189 nimial minima $S$ nutrimentum] nutriuit $P \quad 190$ quod] quia $C W: o m . P V$ in specie fumi] fưmus $W$ fumil fluit $P V$ et uaporis om. $M$ uapor $W$ ut] et $V 191$ dixit $D W$ secundiom. $W$ nutrimentum] cum add. $W$ descendere] ascendere $M \quad 192$ non] ideo $C:$ om. $M$ plante $M$ simile] substancia $M$ : frigide $P$ : facere $V$ contingit] conuenit $M$ : conueni $P$ : erit $V$ ubi] nisi $M$ 194 siquid $C$ : si queritur $V$ indiget] semine $a d d . M \quad 195$ semine terminato $\mathrm{om}$. $W$ terminato] seminato $P V$ perfectio $P$ maturo] maturato et inalterato $M \quad 197$ conueniente $W$ : coniuncti $B K S$ id est om. $M W$ hec duo] hoc dico $P V \quad 199$ id est] in $M$ humore temperatol humor temperatus $B C K S$ temperatol terminato $M$ conseruatiuol conuenientis $B K S$ : conteritis $C \quad 200$ si om. $M$ sit om. $B K W$ euaporabit] -aret $M$ : aer sit ei euaporare $W$ 201 naturalis ... apertis $o m . D$ poris $o m . B$ nimis] humidus $K$ suffocat $W$ duo] etiam $M \quad 202$ nutrimentum] a add. $K$ : generationem $M \quad 203$ a om. $W$ remota] iterum $B K$ : rerum $P$ : erit $V: o m . M$ quantó aliquis] quando alicuius $W$ remotiorl longior $C$ 204 existentes $M V$ sub septentrione] in atrione $M$ continue] communem $W: o m . M$

191 De plantis 2.4 (Meyer ed., pp. 31-32)

188 Et planta: quando dominabitur in illa aqua, retinebit aerem, nec permittet eum ascendere; et non nutritur planta. Eodem modo siccitas: quando obtinuerit, convertetur calor naturalis ad extremitates, et obturabit vias, per quas erant meatus aquae, et non nutritur planta (ibid., p. 36).

194-200 Totá siquid planta quatuor indiget: animal quoque similiter: semine terminato, loco convenienti (-te Meyer), aqua moderata, aere consimili; cumque haec quatuor perfecta fuerint, nascetur planta, et crescet; quodsi dissenserint (-suerint Meyer), debilitabitur secundum dissenšum" (ibid.).

203 'Loca vero $a$ sole remota non erunt multarum plantarum, animal (animalium Meyer) quoque similiter, quia sol producit longitudinem diei in remotione sua, et comprehendit humorem illum, nec habebit planta vires folia et fructus producendi' (ibid.). 
205 medium annum, per reliquum noctem. Ibi ergo raro nascitur uel crescit planta uel animal: in estate enim non potest propter continuationem caloris; in hyeme non potest propter continuationem frigoris.

EODEM MODO IN OLEIS. Olee uel oliue uiscosam habent humiditatem, unde difficiliter attrahunt. Vnde uno anno uacant attractioni, alio fructus productioni;

210 et ideo ut plurimum olee uno anno sunt steriles, alio fertiles. Eo tamen anno quo sunt fertiles producunt folia et flores ex materia liquidiori et digestioni obedientiori, sed non fructus, quia parum digerunt.

SPINE. Spina numquam fit in planta, nisi cuius humor est uiscosus, quem cum propellit aer, ut spiritus nutrimentum in corpore animalis, nec possit

215 ascendere propter opilationem ex uiscositate, lateraliter erumpit in conum et acutum. Sic omnis ignis et aer in forma piramidali ascendit.

VIRIDITAS. Hec est ratio uiriditatis extrinsecus in arboribus, sicut in omnibus

205 annum] et $M \quad$ per reliquum] et mediam $W$ reliquum] tantum $P$ noctem] necesse $M$ raro] rara $C D K S: \operatorname{rana} B \quad$ crescit] ibi add. $M \quad 206$ uel] ut $M$ continuationem (solis et add. $M$ ) DM: connuacionem sic $C$ : continuitatem $W$ : contencionem (uel intensionem add. $V$ ) $B K P S V$ hyeme] ueroadd. $V W \quad 207$ potest om. $M$ continuationem $D M$ : continuitatem $W$ : contencionem BCKPSV 208 oleis] oculis $M$ uel] et $M$ : om. PVW uel oliuel enim BCKS uiscosam] -osque $M P$ : unctuosam $W \quad 209$ difficulter $M W \quad$ uacant attractioni] uocant attractionem $P \quad 210$ et ideo om. $W$ alio fertiles om. $V$ fertiles] anno add. $W$ : steriles $B P$ eo] eodem $M \quad 211$ quo] quod $M$ fertiles] steriles $M P V$ digestiorisic $P \quad 212$ non om. $B$ quial et $P V$ parum] rarum $M_{i}$ digerunt] -untur $W 213$ spine] sperme $M: o m . W$ spinal sperma $M$ fit] sit $B$ est uiscosus] unctuosus $W$ quem] quoniam $M:$ quod $P S V: o m$. $K \quad 213-214$ quem cum] quantum $C \quad 214$ cum] tantum $W$ cum propellit] compellit $V$ 214-215 ut... ex om. $W .215$ ex uiscositate om. $M$ uiscositate] in estate $W$ lateraliter] literalitur $C$ : licteratur sic $B$ : naturaliter $M$ erumpit] -at $V$ : prorumpit $M$ in] et $V$ conum] totum $B$ : cornu $W$ et om. $V \quad 216$ acutum] acumen $M$ "sic] sit $K$ : sicut $C M P V$ 217 uiriditas] uerum dicas $B$ ratio om. $K$ sicut] sic $V$ : et add. $B P V W$

208 Eodem modo est judicium in oleis. Sed oleae saepe privantur fructu, quia natura quando digesserit, ascendet primo de subtili, quod non maturavit (-verit Meyer), eritque ille humor folia, eritque illa digestio flores; cumque maturaverit in secundo anno digestio, nascetur fructus, exibitque ad finem materiae secundum locum, qui est in eo' (ibid., p. 39).

213 'Spinae vero non sunt de genere plantae, nec de natura ejus. Sed dico, quod in planta est raritas, et erit in principio naturae decoctio, et ascendit humor et frigus, et cum eis parva decoctio; ambulatque in illa raritate, facitque illud coagulari sol, eruntque ex illo spinae, et ideo erit forma earum pyramidalis' (ibid.).

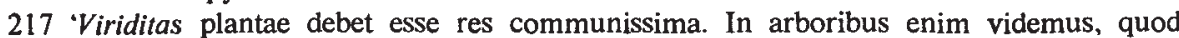
communis (om. Meyer) est interius albedo, et viriditas exterius; et hoc est, quia materia utuntur propinquiori. Oportet ergo, ut sit viriditas in omnibus plantis, quia materiae attrahunt (-huntur Meyer) et rarificant lignum arboris; fluitque (facitque Meyer) calor parvam digestionem, remanetque ibi humor, apparetque exterius: erit ergo viriditas. Et hoc est in foliis nisi quia major inest digestio, et ipsa sunt media inter rosam (casuram Meyer) et lignum in potentia. Sed viriditas non moratur, nec est nisi humor in illa, estque de genere terrae, fitque inter illa ambo viriditas (color viridis Meyer). Hujus est (autem Meyer) signum, quod cortices arboris quando arescunt, 
terre nascentibus, quia calor aeris, plurimum habundans extrinsecus, nutrimentum arboris, scilicet humorem uel terreum uaporem, ut plurimum trahit ad exteriora. In quo humore, cum sit multa aquositas et debilis agens caliditas, est color uiridis. Et quod materia plurimum sit terrea patet, quia desiccata humiditate remanet cortex nigra.

In foliis autem quibusdam maior habundat aquositas cum aliquantula terreitate. Vnde et in eis non est adeo intensa uiriditas, quod patet, quia cum 225 arescunt fiunt citrina. Interius autem melior celebratur digestio propter temperatam humiditatem et non superhabundantem. Et ideo arbor alba interius uel secundum naturam nutrimenti colorata, ut inferius dicetur.

FigVRE PLANTE. Quedam planta magis tendit sursum quam deorsum, et hoc ideo quia eius materia aerea est magis quam aquea uel terrea. Que utique 230 aeream habet materiam et directos poros et amplos procera fit, ut fraxinus,

218 aeris] in add. $V \quad 218-220$ habundans ... trahit om. $W \quad 218$ extrinsecus] exterius $P V$ 219 nutrimentumque $M \quad$ arboris scilicet] scilicet arboris $P V$ : scilicet add. $P$ humore $M$ uel] et $B C K S$ terrenum $P$ ut] et $V \quad 220$ attrahit $W$ ad] inferiora add. $D: o m$. $V$ cum sit] est uel cum fit $S$ multa] mala $V$ agens] aeris $W \quad 221$ color] calor $B C$ terrea] terra $M$ : terreaque $P$ : terre et aque $V$ patet] paret $M: o m . B$ quial quod $V 222$ nigral niger $M$ : magna $W 223$ quibusdam] in quibus $V$ magis $C$ aquositas] aqueitas $B C K S$ : humiditas $M \quad 224$ terreitate] terrestritate $M$ : humiditate $W$ et $o m . M V W$ eis] unde et in eis add. $P$ adeo] causa $B V: \operatorname{tam} C K M P S:$ om. $W$ uiriditas] nisi yditas sic $C$ : humiditas $W$ quod] quia $P:$ ut $M$ quial quod $S:$ om. $V \quad 225$ arescuntl atascunt (?) $V$ fiunt] sunt $W: o m$. $P V$ citrinal cerulia(?) $B$ interius] intius $V$ melius $W$ celebrat $V 226$ temperatam humiditatem] temperantiam humiditatis $M$ arbor] est $a d d . M$ albal alta $V$ interius] intius $V$ : intrinsicus sic $W \quad 227$ uel om. $S W$ coloratur $W \quad$ utl in add. $K$ dicetur] diceretur $B$ 228 quam] quedàm magis $M \quad 228-229$ hoc ideo] hec est ratio $P V W \quad 229$ quia] quod $V$ aqueal aquatica $W$ que] qua $V$ utique] utrumque $C$ : ut $B K S$ : autem $W 230$ aerem $K$ : aere qui $P$ :-terream $W$ habent $W$ materiam] naturam $B C$ procera] quod cera $B$ : et ipsa $M$ : posita $P$ : poma $V:$ om. $W$ fit] sunt $C$ : om. $P V W$ fraxinus $B C D K W$ : fraxius $M$ : fraxinis $P$ : fraxunus $S$ : fagus $V$

220-221 Cf. Alfred: 'Hic enim color [i.e., viriditas], et post adustionem residente calore, ut in quibusdam humoribus, et ante maturitatem, ut in foliis arborum, evenit' (Comm. in Meth. 3, cap. de yride [Otte ed., p. 70]).

denigrantur, et sunt (fiunt ligna Meyer) alba interius, fitque in illis inter illos duos colores color viridis in apparenti plantae' (ibid., pp. 39-40).

228 'Figurae autem plantae tres sunt modi. Quaedam enim sursum prodeunt, quaedam deorsum, quaedam inter haec. Sed quae tendit sursum, est quia materia ejus apparet in medulla plantae, et attrahit calor, et comprimit ipsum (ipsam Meyer) aer, qui est inter raritates ipsius, pyramidaturque, sicut pyramidatur ignis in suis materiis, et elevatur. Quae autem deorsum tendit, meatus coangustantur; cumque digesta fuerit materia, inspissabitur aqua, quae est in medulla plantae, proceditque subtile sursum, convertiturque aqua ad partes illas deorsum, movetque illam sua ponderositate. Quae vero inter duas partes fuerit, subtiliatur humor, et natura vicinatur temperantiae in digestione, eruntque meatus medii, tenduntque materiae sursum et deorsum' (ibid., pp. 40-41). 
abies. Et ideo abies leuis est et mollis propter eius aeritatem. Alia autem magis crescit deorsum quam sursum, in quibus aquea habundat materia que opilans poros, ne aer possit ascendere, et eum ponderositate sua deorsum comprimit. Alia equaliter crescit sursum et deorsum, in qua scilicet.iste cause equaliter 235 conueniunt, ut esculus.

EST AVTEM PRIMA DIGESTIO. In planta sunt tantum due digestiones: prima in planta cum attrahitur nutrimentum, secunda in medulla. Et hoc ideo quia planta grosse est substantie et parum distat ab elementis et suo nutrimento. Sed in corpore animalis multa est membrorum diuersitas et remota a suo

240 nutrimento. Et ideo in animali necessarie sunt plures mutationes, et "ideo ibi triplex digestio.

FIGVRE vero. Figura plante prouenit secundum quantitatem seminis et eiusdem perfectionem, si non contradicat territorium. Si enim semen sit inperfectum, et planta erit inperfecta ex eo nascens. Sed flos et fructus

245 respondent nutrimento ex quo fiunt.

Et nota quod in materia animalis, scilicet in spermate, est digestio absque omni alio nutrimento adhibito et uegetatio et partium quarumdam generatio, que ex solo spermate generantur. Vnde secundum quosdam sicut in ouo ex uitello generatur fetus èt albumen est eius nutrimentum, sic ex quadam parte

231 abies $^{1}$ ] ab eis $B$ abies ${ }^{2}$ ] et $a d d . C$ lenis $C W$ aeritatem] acritatem $P$ autem om. $M$ 232 crescit] cum sit $M$ in] ut $D$ habundatl humiditas $a d d . M$ opilans] -ant $B$ : -at $W$ 233 aer om. $M$ possit] poscit $B: o m . V$ et eum] in $W$ eum] cum $B K$ comprimit] -at (uel comprimit add. in marg.) $D$ : -itur $W \quad 234$ crescit] -unt $M \quad 234-235$ crescit ... ut $o m$. $W$ 235 conueniunt] sunt $V$ ut esculus om. $V 236$ primal] primus $P$ plante $B$ tantum om. $W$ prima in] unum sub $B K S$ : una sub $C \quad 237$ attrahit $W$ nutrimenti $C$ hoc,om. $W$ ideol est add. $B C K S \quad 238$ plante $K$ grossa $P V W$ substantia $P V W$ et $\left.{ }^{2}\right]$ in $V W$ : a $a d d . P$ 239 multorum $W \quad \operatorname{remotam} K S:$ remptum $B \quad$ a] in $W:$ om. $M \quad 240$ in ... ibi $o m$. $W$ necessarie $D W$ : necessario $M$ : necesse $B C K P S V$ sunt] est $S$ mutationes] intentiones $M$ ibi om. MPV 241 triplex] multiplex $M \quad 242$ figure] figura $V$ : figuere sic $W$ uerol plante $V$ 243 perfectione $P \quad$ contradicat] -it $P V W$ : dicat $S$ enim] autem cồntradicat $M$ semen $o m$. $S W \quad$ sit] scit $B$ : est $M \quad 244$ inperfectum] -ta $W$ erit om. BCKMPSVW sed] et $W$ 245 respondent] -ebunt $W$ fiunt] sumitur $P \quad 246$ in $^{1}$ om. $W \quad 246-247$ absque omni] animalis omnium $S \quad 247$ quorumdam $B C S W$ generatiol genere $S 248$ que] est $a d d . B$ sola $M$ sicut in ouo om. $\left.M \quad \mathrm{ex}^{2}\right] P V W \quad 249$ generantur $K \quad$ fetus] coctus $W$ est $o m$. $B \quad$ sicl sicut $K:$ si $P \quad$ quedam $M$

236 'Est autem prima digestio desub planta, et secunda, quae est in medulla, quae exit a terra, quae est in media planta; et postea apparent materiae (maturae Meyer) dividunturque, nec digeruntur tertia digestione. Tertia enim digestio est in animali, nec enim fit tertia digestio nisi propter diversitatem membrorum et remotionem naturarum adinvicem' (ibid., p. 41).

242 'Figurae vero plantarum erunt in quantitate seminum; flos vero plantae et fructus sunt in aquis et materiis. Et positus motus primus, maturatio et digestio, in omnibus animalibus; nec recedunt ab hoc. Sed in planta est prima digestio et maturatio secundum nutrimentum' (ibid.). 
250 seminis generatur fetus et reliqua pars est eius nutrimentum. Sed ex semine plante nulla fit generatio nec est in eo actualis uegetacio, nisi prius attraxerit nutrimentum. Sed attracto nutrimento et aliquantulum digesto statim prorumpit in plantam.

Qvel.1BET ARBOR. Planta semper crescit in longum, donec in ea uel ex nimia 255 humiditate uel frigiditate uel duricia uel constrictione inpediatur humiditatis ascensus et discursus. Quo inpedito statim planta desinit esse; arescit enim. Crescit autem continue, quia directi sunt meatus humoris in planta, et omnes partes consimiles; unde humor a poro superiori exiens extendit plantam in longum. Hac eadem ratione generantur noui rami continue in planta, quia si 260 alicubi erumpit humiditas, illic fit discursus.

In corpore animalis non est tanta longitudo, et ideo non uehemens humoris discursus. Nec etiam est tam liber exitus in terminis animalis, sicut et arboris; non enim habent humores liberum ascensum supra caput, sed ibi reprimuntur et obuoluuntur. Membra autem noua non possunt generari in animali propter 265 diuersitatem materie, quia os uel neruus non potest generari nisi ex prima materia animalis.

QvoD AVTEM Folia. Arbores que habent uiscosos humores et difficile digestibiles retinent sua folia; que habent humores liquidos non retinent.

250 seminis] sentimus $S$ generantur $C$ fetus] ita $a d d . P W$ et reliqual ita quod reliqua $V$ : ita $B K$ : qua $C$ : tercia $S$ est om. $B$ semine om. $B \quad 251$ est om. $W$ attraxerit] -erint $P$ : extraxerit $V \quad 252$ nutrimentum om. $V$ sed] si $C$ attractol extracto $V$ et ... digesto om. $M W \quad$ aliquantulum digesto] aliquantulum digestio $K$ : aliqua sibi digestio $P V \quad 253$ in plantam] planta $B C K M S \quad 254$ quelibet] quicumque $S$ arbor] et add. $M$ planta semper crescit] plantata crescit uero $W \quad$ uel] ut ex ea $P: o m$. $W \quad 255$ duricial -ie $V$ : causa $W$ humiditas $M P \quad 256$ ascensus] -dens $M$ et] uel $C$ : om. $P V W$ et discursus om. $M$ decursus $C$ : discensus $V$ quo inpeditol quo impedimento $B$ : qua impedita $M$ arescit enim om. $M \quad 257$ crescit] et fit $M$ autem om. $V W$ directe $V$ sunt om. $M$ humorisom. $V$ 258 parte $B$ pori $W \quad 259$ quia] quod $P V \quad 259-260$ si alicubi] si alicui $S W$ : si alie ibi $B$ : sic ubi $M \quad 260$ illuc $K P S:$ id $W \quad 261$ non ${ }^{1}$ ] est $a d d . K W$ uehemens] uehementis $W$ : debentis $C$ humores $S 262$ tam liber] causa liberalis $W$ in terminis] interius $B C K S$ : racemis șic M: om. $P V$ animalis] cleris $C 263$ super $V$ sed] et $W \quad 264$ et] hic add. $C$ membra] memoria $M \quad 264-265$ propter ... generari om. $K \quad 265$ diuersitate $B$ uel] et $V$ nisi] uis $B$ 267 quod] quia $P V$ foliales $S$ arboris $P$ uiscoso $B:$ multos $M$ humores et] ramos $C$ difficile] de difficili $P V$ : et $a d d . B \quad 268$ retinent'] retinet et $B$ : reiciunt $P V$ que] uero $a d d$. $M$ : autem add. $W$ retinent $\left.{ }^{2}\right]$ reiciunt $P V$

254 'Quaelibet vero arbor ascendit semper, donec compleatur et intereat. Et hoc est, quia cujuslibet animalis longitudo propinqua est suae latitudini; in planta (plantis Meyer) vero remota est, quia radix ejus, aqua et ignis, festinant in ascensu, et procreatur planta. Diversitas vero plantae in ramis est de superflua raritate, cumque comprehensi fuerint humores, calefiet natura et festinabit in digerendo, formabunturque rami et apparebunt folia, ut praediximus' (ibid.).

267 Quod autem folia arborum cadunt, erit propter fluxibilitatem velocis raritatis; cumque digesta fuerit aqua cum materia, pyramidabitur, ideoque erunt meatus interius ampli, et post haec (hac Meyer) graciliabuntur et pyramidabuntur; et quando apparuerit (nutritiva add. Meyer) 
Sed CYm habverint. Planta que habet uirtutem uehementem attrahentem 270 semel fructificat, quia semel perfecte attraxit; que debilem habet attractiuam uicissim attrahit et similiter digerit, sic et fructificat.

PlaNTA VERo. Quatuor sunt genera plante: arbor, frutex, herba, et olus. In herbis et oleribus tanta habundat humiditas quod materia non potest coagulari nec solidari. Vnde post maturatum tempus in herbis superueniente frigiditate 275 repercutitur humor et arefiunt; et ideo olera non durant ultra tercium annum.

VeNETALITAS. Cum arbor crescit in calidissima regione, eius nutrimentum in calore est intensum et in substantia spissum. Quod cum natura uoluerit digerere, propter eius paruitatem circa ipsum intendetur actio caloris, et ita prouenit uenetus color in arbore; eius lignum interius erit nigrum, ut hebenus, 280 et sic secundum maiorem et minorem calorem fiunt omnia ligna inter alba et nigra.

269 sed] si $C S \quad$ sed ... habuerint om. $W \quad$ cum] tum $B K$ : tantum $S$ habet] -ent $B$ 270 fructificat] -ant $W:$ om. $V$ perficere $K$ attraxit] -hit $B C K M S$ attractiuam] attractionem $W \quad 271$ digerit] dirigit $M \quad 272$ plante] plantarum $M \quad 273$ tanta] enim $V$ habundat $o m . B K \quad 274$ nec solidaril et consolidari $M$ unde postl quidem posset $W$ post] prius $V$ maturatum ed.: aliquantulum $B$ : exitum $C$ : anaturatum sic $D S W$ : aliquantum $K M$ : naturarum $P$ : negatum (?) $V:$ uel antiquum add. in marg. $D$ temporis $C$ : tempore $W$ frigiditate] et $a d d . P V \quad 275$ percutitur $C$ : reprimitur $M$ tercium annum] terennium $M$ 276 uenetalitas $D$ : uentalitas $M W$ : ueneralitas $V$ : uenerabilitas $P$ : uegetalitas $S$ : uegetasitas $B K$ : uegetabilitas $C 277$ calore] colore $D$ in om. $P V$ in substantial mixtum $M$ : spongiosum $W$ spissum om. $W$ quod] et $C$ cum om. $P$ natura] nota $V$ 278 digerere] dispergere $W$ propter] per $B$ ipsum] eum $D$ intendetur] -itur $M:-$ it $W \quad 279$ peruenit $K M P$ uenetus] uentus $B W$ : uenesus sic $V$ : interius $M$ color $D P$ : colorem $B$ : calor $C K M S V$ : caloris $W$ in $o m . B$ in arbore om. $M$ lignum] signum $P V$ nigrum om. $P V$ ebanus $W$ 280 sic] sit $C K S$ : sunt add. $M$ minorem om. $B$ calorem om. $C V$ calorem fiunt om. $M$ fiunt] sunt $W$ intus $B C$ : interius $W$

materia cum digestione completaque perfectione, obturabit extremitates meatuum superius, nec habebunt folia materiam; siccantur ergo. Et cum contrario ejus, quod diximus non cadit (cadunt de Meyer) planta' (ibid., pp. 41-42).

269 'Sed cum habuerint arbores vel plantae virtutem attrahentem vehementer, erit fructificatio una; quam si non habuerint, utetur natura digestione vicissim, et in qualibet digestione fructum producunt, et ideo quaedam plantae saepe in anno fructificant' (ibid.. p. 42).

272 Planta vero, quae est sicut natura aquae, vix fructificat propter dominium humiditatis suae et amplitudinem meatuum suorum et fluxibilitatem suarum radicum; cumque incanduerit calor, festinabitur ejus digestio, et subtiliabitur propter aquam, et non coagulabitur; et istud (ita Meyer) invenietur in omnibus herbis minutis et aliquibus oleribus' (ibid.).

276 'Venetalitas autem erit in terris vehementer calidis; et erit ibi parum (humoris add. Meyer), et fient angusti meatus; cumque voluerit natura digerere, non habebit humorem, qui sufficiat materiae, fiuntque (fientque Meyer) meatus angusti. Revertetur (-titur Meyer) ergo digestio, continebitque eam calor, videbiturque inter albedinem et nigredinem in colore. Quod autem hoc modo fuerit. lignum habebit nigrum et omne, quod approximatum fuerit inter albedinem et ebęnum, et hoc est ab ebeno usque ad ulnam (ulna Meyer)' (ibid., pp. 42-43). 
QVOD VERo IN PLANTA. Planta que habebit terream materiam erit in colore ut nigrum; que aqueam erit album eius lignum; que habebit materiam inter utramque temperatam erit lignum eius glaucum.

285 QvoD AVTEM QVEDAM. Quedam arbores grossos et uiscosos habent humores, et ideo non possunt subtiliari, et ideo non habent flores, ut ficus. Quedam adeo liquidos habent humores quod non possunt digeri, et ideo carent floribus, ut palma.

Planta vero. Planta que grossum habet corticem et durum multum crescit in 290 longum, quia calor exterior parum attrahit de nutrimento in latitudinem; quare interior uigens circa interiora multum potest humorem circa longitudinem extendere.

SED PLANTA. In plantis que habent lac fortis est prima digestio in radice, ita ut unctuosus fiat humor, qui cum dequoquatur secundo in medulla, transit in lac, 295 quod uapor inde generatus ad exteriora transmittet. Sed cum non poterit

282 quod] que $V$ planta ${ }^{2} \mathrm{om} . V$ habet $P V W$ materiam $D K$ : naturam $B C M P S V$ : naturam id est materiam $W$ in om. $V$ colore] calore $B C S$ ut om. $P V \quad 283$ nigrum om. $B C K S$ aqueam] ad queam $C$ habebit] habet $P V$ : autem $W$ materiam] naturam $B C M W$ 283-284 inter utramque om. W 284 utramque] utrumque $M V$ : terminatam add. $V$ temperatam] imparatam $S \quad 285$ quedam $^{2}$-om. $S V \quad 286$ subtiliare $W$ non²] nunc $V: o m . P$ ficus] sicut $P$ quedam] que $W \quad 289$ planta uero om. $W$ planta ${ }^{2}$ uero $a d d . K W:$ om. $V$ que] quia $S$ : multum add. $M$ habent $W$ corticem] humorem $M \quad 290$ quia] quod $S$ quare] quia $C M S W \quad 291$ uigens] in generacione $P V$ : digestio $W \quad$ circa $^{2}$ ] in $P V W$ longitudinem] latitudinem $C \quad 293$ fortis est] fortasse $W \quad 294$ unctuosus] -itas $V$ qui om. $P V W$ secunda $B C M W$ medullam $V$ transit] crescit $W \quad 295$ quod $D W$ : quia $B C K M S V$ : que $P$ inde] in deinde $W$ transmittet $B D S$ : -it $C$ : -etur $K$ : -itur $P V$ : transiuit $M$ : transmutatur $W \quad$ cum] tamen $W$ : causa $V: o m . B K$ cum non poterit $o m . M$ non] nunc $V$

282 Quod vero in planta angustarum partium fuerit, erit in colore ut lazulum, et quando non comprimentur partes ejus, ad albedinem declinabit, cumque temperatum fuerit, erit glaucum (ibid., p. 43).

285 'Quod autem quaedam flores non habent, ut plurimum fit propter diversitatem suarum partium, et suam subtilitatem et asperitatem vel (et Meyer) grossitudinem. Non ergo habent flores, ut palma et similia' (ibid.).

289 'Planta vero, quae grossos habet cortices, extenditur propter tensionem humoris et impulsionem caloris; et hoc est in pinu et palma' (ibid.).

293 'Sed planta, quae lac emittit, habebit lac in medio, eritque calor subterius fortis, eritque ibi unctuositas; cumque inceperit calor digerere, vertetur (conver-Meyer) unctuositas in illum humorem, et coagulabit ipsum cum coagulatione parva, et calefiet locus, fietque aqua unctuosa similis lacti, elevabiturque vapor ab humore, qui attrahit lac illud ad extremitates, et retinebit humor calorem (co-Meyer) apparentem. Et non coagulabitur illud lac, quia usus est caloris, ut coagulet lac. Et quodlibet lac multae est coagulationis, cumque (cum Meyer) fuerit in arbore frigus apparens, coagulabitur lac, postquam exierit a loco, et inde erunt (erit Meyer) gummi’ (ibid., pp. 43-44). 
coagulari et digeri in estate impediente calore incluso in uiscositate ipsius, qui ipsum dissoluit, et ita coagulationi resistit. Superueniente autem frigiditate coagulatur perfecte. Similiter si erumpat, intensa existente caliditate in aere coagulabitur. Vnde numquam gummi coagulatur nisi caliditate uel frigiditate 300 intensa.

Gvmme vero calide. Gumme numquam coagulantur nisi ex nimia caliditate uel ex nimia frigiditate. Vnde gumme que in aere temperato stillant, non coagulantur. Sed tamen auctor uidetur uelle quod gummi numquam coagulatur ex frigiditate nisi ex humore lacteo et uiscoso, ut in premisso capitulo 305 ostenditur. Caliditate autem coagulatur etiam humor liquidus, dummodo sit calor uehemens. Sed liquidus humor calore mediocri non potest coagulari.

ArBorvm QVEDAM. Quedam arborum, ut buxus, in estate est uiridis, in hyeme glauca; quia habet uiscosum humorem in se, in radice autem multam humiditatem et liquidam, et ideo non cadunt folia. Vnde adueniente caliditate

310 prouocatur humor ad exteriora, qui tactus calore fit uiridis. Adueniente

296 coagulari om. $S \quad$ in $^{2}$ ] et etiam $M: o m . C$ uiscositate] unctuositate $M$ ipsius qui] ipsum quod $V 297$ frigiditate om. $M 299$ coagulatur] -antur $V$ nisi] ex add. $C$ : in add. $W$ : ex manifesta $a d d . M \quad 301$ gummel] gummi $W$ : gramine $M$ calide om. $C P V W$ gumme ${ }^{2}$ gummi $W$ : gramine $M$ coagulantur] -atur $M W \quad 302$ uel] nec $K$ gumme] gummi $W$ : gramine $M$ stillant] sistant $K$ non] numquam $M \quad 303$ tamen] tantum $M W$ uelle om. $V$ uelle ... numquam om. $P$ numquạm] non $M$ coagulatur] -antur $B V$ : gelantur $P \quad 304$ in] predicto et $W \quad 305$ caliditate] calante $S$ : celerante $B$ : coagulante $K$ coagulatur] congelatur $W \quad$ sit] fuerit $M$ : fit uel sit $V \quad 306$ calore] calori $W \quad 307$ arborum ${ }^{1]}$ arbor $B C W$ arborum ${ }^{2}$ ] arbor $B C W \quad 308$ glaucum $M \quad$ in $\left.^{2}\right]$ etiam $S$ autem] aut $S: o m . C D$

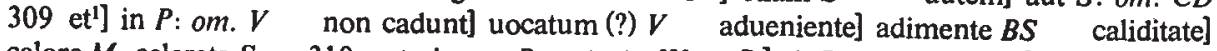
calore $M$ : celerate $S \quad 310$ exterioram $B \quad$ tactu, $W \quad$ fit] sit $P \quad$ adueniente] adimente $B S$ : adinuicem $K$

304 De plantis 2.15 (Meyer ed., pp. 43-44).

301 'Gummae vero calidae procedunt distillando, cumque aerem tetigerint, coagulabuntur. Et quaedam manant in loco temperato, et erunt similes aquae; quaedam vero manant et coagulantur, similes lapidibus vel conchis. Sed quod guttatim manat, remanens (-net Meyer) in forma sua (et add. Meyer), erit ut arbor, quae dicitur aletafur. Quod vero alteratur ut lapis, erit in apparentia valde frigidum, et faciet calor ipsum apparere, cumque manaverit, lapidescet, fietque in terra calida superflue' (ibid., p. 44).

307 'Arborum autem quaedam alterantur in hieme, fientque quandoque virides quandoque glaucae, et non corrumpuntur folia earum nec fructus, quia arbores, quibus accidit hoc, habebunt calorem grossum, et in barbis inferioribus aquam subtilem. Ergo in processu anni retinebit aqua illa calorem propter frigiditatem aeris; et quia accessit calor ad frigus, impulit (-pell- Meyer) calor humiditatem exterius cum eo, quod (qui Meyer) tinxit colore caloris, et apparet ideo color in apparente arboris. Consequenter vertuntur (-ti-Meyer) frigus et caliditas ad actum, et humor retinet calorem, et ideo apparet alius color. Fructus vero erit amarus, quia calor et humor non sunt completi in digestione; frigus quoque et siccitas impediunt, ut compleantur; convertuntur ergo ad amaritudinem. Hujus signum, quod amarum missum in ignem dulcescit' (ibid.). 
frigiditate repercutitur humor, et habundat siccitas, et fit color glaucus: Fructus in principio est amarus, quia habundat in eo frigiditas. Et sic quia hic dicitur amarus sapor uulgariter acidus, tamen in hoc est differentia: si sit frigiditas et siccitas cum grossa substantia, erit ponticus; si cum liquida substantia et suptili,

315 acidus uel amarus. Deinde perfecta digestione succedit caliditas et humiditas, sine quibus nulla fit digestio, et ita fit dulcis.

ARBORES QVE NASCVNTVR in aqua acetosa attrahunt humorem acetosum, scilicet sibi similem, qui est frigidus et siccus. Illud quod arbor sibi incorporat digerit et facit dulce. Reliquum autem minus digestum emittit in fructus et folia.

$320 \mathrm{Et}$ ideo fructus eius, primo acidus, conualescente calore et humore per digestionem fit dulcis. Sed quia ibi pauca est humiditas et multa caliditas, cito consumitur humor, et succedunt caliditas et siccitas, et fit fructus amarus.

ARBORES QVE NASCVNTVR in loco temperato ante uer fructum producunt, quia, cum aer sit temperatus continue, aperti erunt pori aderitque humor liquidus et 325 digestibilis, qui leui calore poterit digeri, ad fructus productionem.

311 fit color] fit calor $B$ : sic calor $P V \quad$ fructus] fictus $B$ : eius add. $W \quad 312$ frigiditas] humiditas $S \quad$ quia $\left.{ }^{2}\right]$ quod $C W$ hic om. $P$ dicitur] fit add. $W \quad 313$ uulgariter] accidet add. $M \quad$ tamen] cum $P \quad 314$ cuml] ac $P V^{1}$ si] sed $C S \quad$ si cum] sicut $P$ cum ${ }^{2}$ ] autem $V$ : om. $C$ liquida] aerea $W \quad$ 315-339 deinde ... unde fit amarus [i.e., usque ad finem] om. $C$ 315 succedit] -eret $B K S$ : incedit $W \quad 316$ fit $\left.^{1}\right]$ est $B K S$ ita] ideo $V$ [it'] sit $B$ 317 arbores] uero $a d d$. $B K S$ aqual qua $V$ attrahunt] -it $W \quad 318$ scilicet] sed $W$ : om. $D K$ illud] id $W$ arbor] aliquis add. $W$ sibi om. $W \quad 319$ digerit] dirigit $M \quad$ in] ut $B$ 320 primo] post $B:$ om. $M W$ acidus] a principio acidus add. $M$ et humore om. $P V \quad 320$ 321 per digestionem] secunda digestione $W \quad 321-322$ cito ... caliditas om. $P V W$ 322 consumitur] confiunctur (?) $B \quad$ succedunt] -it $B K$ et ${ }^{3} \mathrm{om}$. $P V W$ fit] sic $V$ fructus] frigus $B \quad 323$ antel an $P$ ante uer] aut nec habent $S$ uer] bonos $W$ fructum producunt om. $M \quad 324$ sit] fit $B M:$ om. $V$ apertique $D$ erunt sunt $P V W$ aderitque $B C D$ : adheritque $P V$ : aderit quia $S$ : aderit $K M$ : adheret $W \quad 325$ qui] quia $S$ : quare $B K$ : cum $P V W$

317 Arbores autem, quae nascuntur in aqua acetosa faciunt fructum dulcem, quia acetositas attrahit cum calore solis, quod fuerit (est Meyer) suae qualitatis, et hoc est frigus et siccitas. Apparent ergo aquae intrinsecae dulces, calefitque venter arboris, quando perseveraverit super eam sol, eritque sapor fructus acidus (acetosus Meyer) in succione (successione Meyer), et quando plus digestum fuerit, dissolvetur paulatim acetositas, donec comsumatur (-metur Meyer), apparebitque dulcedo. Erit ergo fructus dulcis, foliaque sua et extremitates acida. Cumque perfecta fuerit maturitas (-ratio Meyer), erit amarus; et hoc est propter superfluum calorem cum pauco humore. Et consumitur humor, facitque fructus calorem ascendere, eritque amarus, eruntque nuclei ejus pyramidales propter attractionem caloris superius, et frigiditatis et humiditatis (humoris Meyer) inferius, quae sunt ex genere aquae acetosae, remanetque humor in medio, inspissaturque (-sabiturque Meyer) medium et graciliantur extremitates. Arbores vero, quae fuerint in terris temperatis, accelerant maturationem ante dies vernales, quia calor quando fuerit prope temperantiam, fueritque humor apparens, aerque clarus, non egebit fructus multo calore in digestione. Festinat ergo ejus maturatio, provenitque ante dies vernales' (ibid., pp. 4445). 
OMNIBVS QVIDEM NOTVM. In principio generationis fructus habundat frigus in materia eius, in quo, si dominetur humiditas, fructus erit acidus uel amarus; si siccitas, ponticus.

MirabVlanORvm. Nota: arbor mirabulanorum poros habet mediocres et habet 330 uirtutem digestiuam equalem uirtuti attractiue. Vnde humorem attractum statim digerit. Vnde fructus in sui productione est dulcis. Communiter autem habundante calore extrinseco constringuntur pori siue fructus siue arboris, et ita obstruitur uia humoris, in quo etiam includitur calor naturalis. Vnde in fructum subit frigiditas et siccitas. Vnde fit ponticus sapor. Postea augmentata

335 constrictione augmentatur frigiditas et siccitas in fructu. Vnde et intensior ponticitas. Ad ultimum uero conualescente calore naturali ex opilatione pororum tandem -uehementer prorumpit, poros aperit, et calore exteriori adiutus uehementer agit in fructum eum décoquendo et calorem et sîccítatem inducendo. Vnde fit amarus. Explicit.

326 quidem] quid $V$ frigus] fructus $P V:$ om. $W \quad 327 \mathrm{si}^{1}$ ] sibi $K$ humiditas] habundans frigiditas $W$ erit] eius $M \quad 328$ ponticus om. $W \quad 329$ mirabulanorum ${ }^{1}$ ] mirabolanorum $K$ :

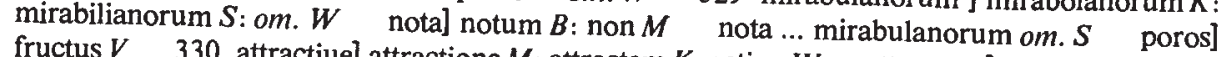
$\begin{array}{ll}\text { fructus } V & 330 \text { attractiue] attractione } M \text { : attractem } K \text { : actiue } W \text { attractum] acutum } M: o m . K\end{array}$ 331 est $o m . W \quad$ communiter] consequenter $P V W \quad 332$ calore] humore $M$ pori] pora $B$ siue] scilicet $W \quad$ arbores $P V \quad 333$ obstruitur] abstrahitur $W$ uia humoris] materia $W$ quo] qua $W \quad 333-334$ in fructum] instructum $B \quad 334$ fructum subit] fructuum subiectis $K \quad$ frigiditas et siccitas] frigidis et siccis $K \quad 335$ constructione $B$ augmentantur $S$ in] et $P \quad 336$ opitulatione $M \quad 337$ et] ex $W \quad$ calorel naturali $a d d . S \quad 338$ adintus $B$ : adiuctus $K \quad$ uehementer agit om. $M$ eum] cum $K$ calores $W \quad 339$ explicit] commentum libri uegetabilium $a d d$. $K$ : commentum alueredi super de plantis add. $V:$ tractatus de uegetabilibus et
plantis $a d d . W:$ om. BMPS

326 'Omnibus quidem arboribus, cum primum plantatae fuerint, dominabitur amaritudo vel ponticitas. Causa: humor quando fuerit in extremitatibus illarum, et digesserit loca, quae sunt in medio arborum, de quibus erunt materiae (fructus add. Meyer), proveniet siccitas, et consequetur et hurem, fietque prima digestio acida vel amara vel pontica. Causa, quia cum (in Meyer) calore et humore est digestio, cumque vicerit humor vel siccitas calorem, erit ex eo fructus in principio non bene digestus; et ideo generatio fructuum in principio est praeter dulcedinem' (ibid., p. 45). consequenter pontici, vero arbores sunt in principio, cum apparuerint fructus, dulces, consequenter pontici, et in completione amari. Causa (eius quia add. Meyer): arbor ejus rara nimis, et in hora digestionis, cum sint meatus ampli, sequitur (-que-Meyer) calor humorem, et maturabit fructum. Erit ergo in principio dulcis. Consequenter attrahit calor siccitatem sibi ergo fructus ad pontificitatem, vincentque frigiditas et siccitas calorem et humorem. Alterabitur

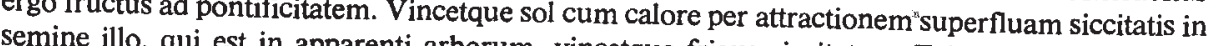
semine illo, qui est in apparenti arborum, vincetque frigus siccitatem. Erit ergo fructus fortis ponticitatis. Deinceps vero ascendet calor naturalis sursum, et adjuvabit eum calor solis extrinsecus. Vincent ergo calor et siccitas et erit fructus amarus' (ibid., pp. 45-46). 


\section{APPENDIX A}

The most troublesome set of variants occurs in the sentence 'Vnde post _ tempus in herbis superueniente frigiditate repercutitur humor et arefiunt ...' (11. 274-275). D, S, and W read anaturatum, though W's scribe, probably uncomfortable with the word, separates the a-privative from naturatum with a slash (a/naturatum). Other scribes venture words that make some sense but are clearly guesses: aliquantum KM; aliquantulum B. P tries naturarum, which makes no sense, and its brother (or cousin) V reads negatum, which is also nonsense. C's reading, exitum temporis, is plausible but poetic.

There are persuasive arguments for reading the neologism anaturatum: it is the lectio difficilior; it appears in D, which has proved to be the most trustworthy witness; it appears also in S, which is a member of another family; and lastly, signifying something like 'unseasonable', it makes sense.

On the other hand, if Alfred coined the word, it appears in none of his other extant works. There is, moreover, no evidence of its usage by any other Latin author, ancient or medieval. Further, a misreading of an initial ' $m$ ' for 'an' is an easy palaeographical slip, as Dr. David Howlett has suggested to me in a private correspondence. maturatum not only makes good sense here but Alfred uses a similar expression ('in tempore maturationis') in his commentary on the Meteorologica (Otte ed., p. 90). The slip must have occurred, however, as early as the apograph, since anaturatum appears in both families.

\section{APPENDix B}

I know of no other word that has suffered so many misreadings and occasioned so many misdirected comments as uenetalitas (see above, p. 162). As Alfred's commentary makes clear, uenetalitas or 'blueness' (or 'a grey color' in E. S. Forster's translation of the De plantis) is the correct reading. The scribes of Alfred's tractatus, however, copy this rare word as uegetasitas, uegetabilitas, uegetalitas, ueneralitas, and uentalitas. Only $\mathrm{D}$ has the correct reading. Although Meyer's judgement was unerring in this instance (p. 127), the scribes of the De plantis were equally catholic in their readings. A limited survey of the manuscripts netted the following variants: uenabilitas, uenecalitas, ueneralitas, uenalitas, and uene caliditas. Albert's copy text had uentalitas, 'windiness', which led him to miss completely the point of the passage: 'Ventalitas quaedam innascitur lignis sive ventositas in terris vehementer calidis, quarum calor, extracto humido aqueo, facit spirare terrestrem substantiam plantarum' (De vegetabilibus 4.4.1 [p. 276]).

Adam of Buckfield's commentary is not far off the mark, since he had access to Alfred's glosses; notwithstanding, his copy text read uene caliditas (Berlin, Staatsbibliothek Preussischer Kulturbesitz Lat. qu. 906, fol. 42r and Vatican Library Vat. lat. 5988, fol. $18 \mathrm{v})$.

Fairfield University. 


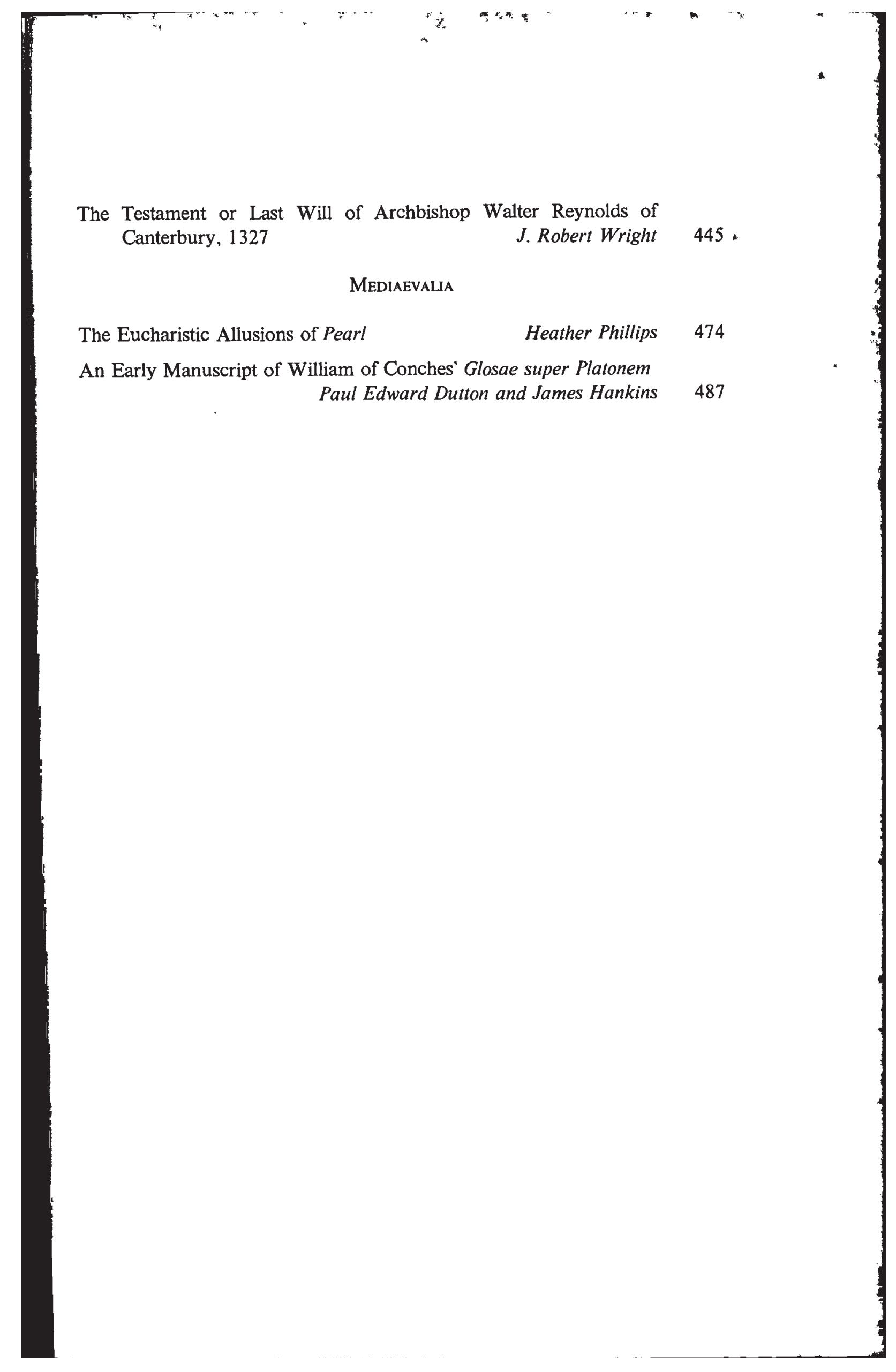

